$$
\begin{aligned}
& 00.07-0.7 \\
=\quad & 1.1000-199
\end{aligned}
$$
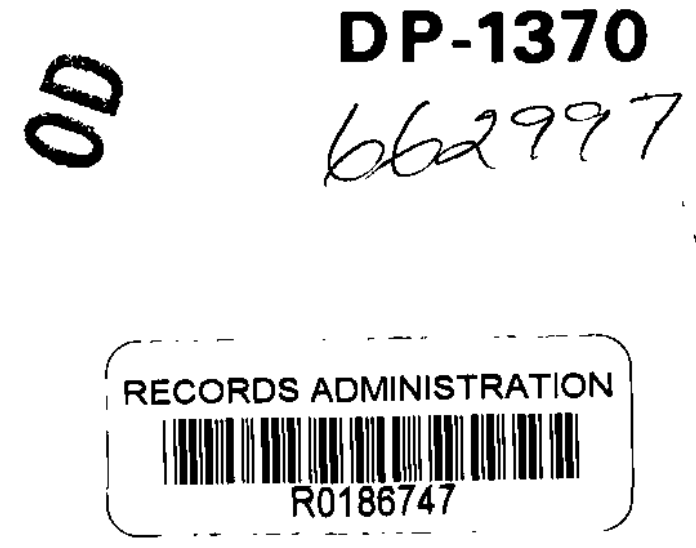

\title{
RADIOACTIVITY FROM SRP OPERATIONS IN A DOWNSTREAM SAVANNAH RIVER SWAMP
}

W. L. MARTER

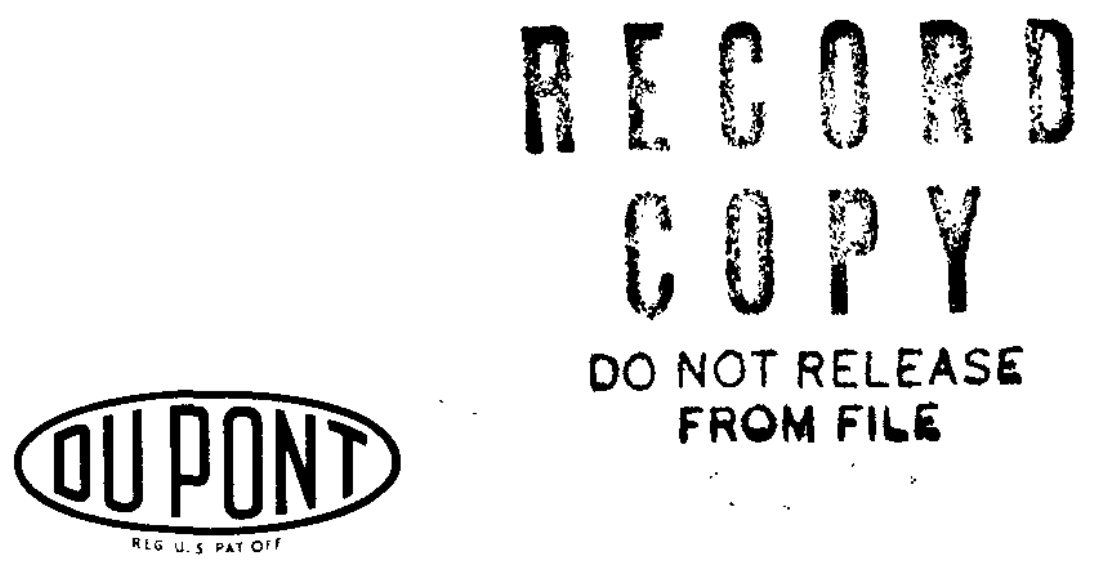

E. 1. du Pont de Nemours \& Co. Savannah River Laboratory Aiken, S. C. 29801 


\section{NOTICE}

This report was prepared as an account of work sponsored by the United States Govermment. Neither the United States nor the United States Atomic Energy Commission, nor any of their employees, nor any of their contractors, subcontractors, or their employees, makes any warranty, express or implied, or assumes any legal liability or responsibility for the accuracy, completeness or usefulness of any information, apparatus, product or process disclosed, or represents that its use would not infringe privately owned rights.

Printed in the United States of America Available from

National-Technical-Information-Service-

U. S. Department of Commerce

5285 Port Royal Road

Springfield, Virginia 22151

Price: Printed Copy $\$ 4.00$; Microfiche $\$ 1.45$ 


\title{
RADIOACTIVITY FROM SRP OPERATIONS IN A DOWNSTREAM SAVANNAH RIVER SWAMP
}

\author{
by
}

W. L. Marter

\author{
Approved by \\ B. C. Rusche, Di rector \\ Environmental Sciences Section \\ Publication Date: September 1974
}

E. I. du Pont de Nemours \& Co. Savannah River Laboratory

Aiken, S. C. 29801

PREPARED FOR THE U. S. ATOMIC ENERGY COMMISSION UNDER CONTRACT AT(07-2)-1 


\begin{abstract}
Approximately 25 curies of cesium-137, less than 1 curie of cobalt-60, and trace amounts of strontium-90 were deposited in about two square miles of swamp bordering the Savannah River and adjacent to the southeast Savannah River Plant boundary. Most of the radioactivity was released to on-site streams in the 1960's from reactor area irradiated fuel storage basins. During the period of release, annual average cesium-137 concentration in onsite streams never exceeded $3.0 \%$ of the concentration guide of $2 \times 10^{-5} \mu \mathrm{Ci} / \mathrm{ml}$, and concentrations in the Savannah River never exceeded $1 \%$ of the guide. Most of the radioactivity in the offsite swamp is associated with kaolin clay particles deposited in the the swamp during river flooding which occurred about $23 \%$ of the time each year. Gamma exposure rates in the affected area of the off-site swamp range from 30 to $590 \mathrm{mR} /$ year above background. The swamp is uninhabited, and the most likely incremental radiation dose (above background) to hunters and fishermen who spend from a few hours to several hundred hours in the swamp would range from less than $1 \mathrm{mR}$ to a few tens of $\mathrm{mR}$ per year. No restrictions on use of the swamp are considered warranted nor are remedial actions needed.
\end{abstract}

The contaminated sediments are relatively immobile and are expected to remain so. Releases of radioactivity to on-site streams were sharply reduced following 1969 when improvements were made in reactor effluent control. No increase in exposure rates is expected from current releases of radioactivity. However, the swamp will be monitored periodically in the future to provide a basis for continued evaluation. 


\section{CONTENTS}

Page

Summary and Conclusions . . . . . . . . . . . . . 5

Discussion

Creeks on the Savannah River Plant. . . . . . . . . . 7

Savannah River Swamp . . . . . . . . . . . . 8

Sedimentation in the Savannah River Swamp. . . . . . . 16

History of Radioactivity in the Savannah River Swamp . . 16

Source of Cesium-137 in the Savannah River Swamp . . . . 25

Swamp Surveys. . . . . . . . . . . . . . . . . 30

Gamma Exposure Rates in the Swamp . . . . . . . . . . . 31

Cesium-137 Inventory in Swamp Sediments . . . . . . . 33

Other Radionuclides in the Off-Site Swamp . . . . . . 36

Cesium-137 in River Sediments . . . . . . . . . 36

Radioactivity in Wildlife . . . . . . . . . . . . 38

Dose Commitment from Consumption of Wildlife . . . . . . 41

Dose from Residence in the Swamp . . . . . . . . . . . . 42

Hypothetical Doses to Exposed Individuals . . . . . . . 43

Acknowledgment. . . . . . . . . . . . . . . . 43

Appendices

A. Radiation Measurements in the Savannah River Swamp from Steel Creek to Little Hel1 Landing (FS-11

Survey, 1974). .. . . . . . . . . . . . . . 44

B. Radiation Measurements (TLD) in the Savannah River

Swamp from Steel Creek to Little Hell Landing. . . . . 47

C. Radioactivity in Vegetation and Soil in the Savannah River Swamp from Stee1 Creek to Little Hel1 Landing $(1974) . . . . . . . . . . . .449$

References ...................... 51 
Page 4 is not included in the original document.

Dannie C. Aries

leads administration $5 / 17 / 2000$ 


\section{SUMMARY AND CONCLUSIONS}

Approximately 25 curies (Ci) of cesium-137 ( $\left.{ }^{137} \mathrm{Cs}\right)$, less than $1 \mathrm{Ci}$ of cobalt-60 $\left({ }^{60} \mathrm{Co}\right)$, and trace amounts of strontium-90 $\left({ }^{90} \mathrm{Sr}\right)$ were deposited in one-third of a five-square-mile swamp bordering the Savannah River and downstream from the Savannah River Plant

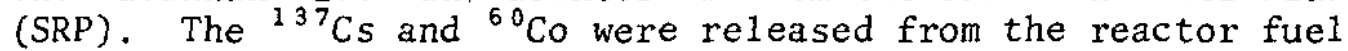
storage basins in the $1960^{\prime} \mathrm{s}$. Most of the radioactivity in the swamp was from releases from $L$ and $P$ reactors to Steel Creek. The discharges to Steel Creek were substantially reduced in 1970 following modifications to one reactor and shutdown of the other reactor.

of the above activity, over $99 \%$ of the ${ }^{137} \mathrm{Cs}$ and ${ }^{60} \mathrm{Co}$ was deposited with sediments in a 4-mile-long section of swamp known locally as the Creek Plantation Swamp. ${ }^{90} \mathrm{Sr}$ was not detected above fallout levels in the sediments, and trace quantities were detected in vegetation. This swamp is between the southeast SRP site boundary and Little Hell Landing on the Savannah River. Aerial radiological surveys by EGEG of Las Vegas, Nevada, indicated that only about $0.3 \%$ of the ${ }^{137} \mathrm{Cs}$ and none of the ${ }^{60} \mathrm{Co}$ were deposited in the 3-mile-long downstream section of swamp between Little Hel1 Landing and the SRP property line at Lower Three Runs Creek. Trace levels of ${ }^{137} \mathrm{Cs}$ were detected at two locations in the off-site swamp just downstream from Lower Three Runs Creek. No other radioactivity from SRP operations was detected by the aerial survey in other off-site areas bordering the Savannah River as far downstream as the Savannah River estuary.

Exposure rates in the affected areas of the swamp from ${ }^{1{ }^{37} \mathrm{Cs}}$ and ${ }^{60} \mathrm{Co}$, measured by both aerial survey and ground survey, range from 30 to $590 \mathrm{mR} /$ year above background. Ground surveys over a 4-year period indicate that the contaminated sediments, deposited during swamp flooding, are relatively immobile and are expected to remain so. Low water velocities in the swamp during flood stage are unlikely to move the sediments or affect the Savannah River. At no time during the history of SRP operations has the concentration of ${ }^{137} \mathrm{Cs}$ in Savannah River water been as high as $1 \%$ of the drinking water 1 imits recomnended by international standards organizations and adopted by the Federal Government. The maximum annual concentration in an SRP stream occurred in Steel Creek in 1964 and was $3.0 \%$ of the guides (for uncontrolled areas). 
The annual radiation dose to a hypothetical person spending full time in the swamp in areas of highest concentration could approach $500 \mathrm{mrem}$ (above background). The more likely annual incremental dose to an individual (or individuals) using the swamp for hunting and fishing would range from less than one mrem to a few tens mrem. The annual dose from natural sources in the Central Savannah River Area averages $120 \mathrm{mrem}$ and ranges up to $500 \mathrm{mrem}$ for persons living in areas of granite and other metamorphic rock outcroppings along the Fall Line.

No restrictions on use of the swamp are considered warranted, nor are remedial actions needed. Discharges from all SRP facilities are maintained at the lowest practical level and are monitored on a continuous basis to assure that off-site releases are minimized. The off-site swamp will be monitored periodically in the future to provide a basis for continued evaluation. 


\section{DISCUSSION}

\section{CREEKS ON THE SAVANNAH RIVER PLANT}

The 300-square-mile Savannah River Plant (SRP) site is drained by six tributaries of the Savannah River: Upper Three Runs Creek, Beaver Dam Creek, Four Mile Creek, Pen Branch, Steel Creek, and Lower Three Runs Creek. Of these creeks, Upper Three Runs has been relatively unaffected by SRP operations; however, the other major creeks have all experienced increased flows from reactor cooling water and have received low-level liquid radioactive discharges at some time during the operating history of SRP. All of the creeks, with the exception of Pen Branch, have wel1-defined mouths or entry points into the Savannah River when the river stage is below flood level. Pen Branch has no mouth, but flows southeastward through the swamp bordering the river on the plantsite and joins Steel Creek before Steel Creek discharges to the river. The creeks serve both as natural drainoff for the SRP site and discharge points for industrial effluents. The creeks currently receive water from the following sources (see Figure 14, page 29, for map):

- Upper Three Runs Creek

Natural drainage

Industrial discharges from the $300 / 700$ areas (SRP support areas including administrative, research, and reactor fuel and target fabrication)

- Four Mile Creek

Natural drainage

Industrial discharges from $200-\mathrm{F}$ and $200-\mathrm{H}$ fuel and target reprocessing areas and $100-\mathrm{C}$ reactor area

Reactor cooling water discharges from $100-\mathrm{C}$ reactor area

- Beaver Dam Creek

Natural drainage

Industrial discharges from the $400-D$ heavy water production and reclamation area

Occasionally, a small portion of the flow of Four Mile Creek 
- Pen Branch

Natural drainage

Industrial discharges from $100-\mathrm{K}$ reactor area

Reactor cooling water discharges from $100-\mathrm{K}$ reactor area

- Stee1 Creek

Natural drainage

Industrial discharges from $100-\mathrm{P}$ reactor area

- Lower Three Runs Creek

Natura1 drainage

Occasional overflow from Par Pond. Par Pond is a 2500-acre artificial impoundment used for cooling and recirculating cooling water to the $100-\mathrm{P}$ reactor.

All of the creeks enter and traverse the Savannah River Swamp before entering the Savannah River. As the creeks enter the swamp, flow channels broaden, water velocity decreases, and heavier waterborne sediments settle and form fluvial deposits.

\section{SAVANNAH RIVER SWAMP}

The Savannah River meanders along the southern boundary of the Savannah River Plant. During ages past, this meandering has formed a broad river valley (or fluvial belt) of alluvium through which the river continuously changes its path through erosional processes. At present, the portion of the river bordering the SRP site consists of several long reaches with channel meandering restricted by erosion-resistant high ground on the south side of the river. Most of the flood plain in this area is on the north side of the river. The portion of the river between Steel Creek and Little Hell Landing makes many meanders (Figure 1) back and forth across the river valley.

During periods of high water flow, the suspended sediment load of the river increases, and as the river overflows to the flood plain, the current is reduced at the margin of the river channel, and the coarser part of the sediment load is deposited there. Thus, a small embankment or natural levee is built up at the point of flow over the bank. Beyond this natural levee, the ground slopes downward and is marshy with stands of large cypress 


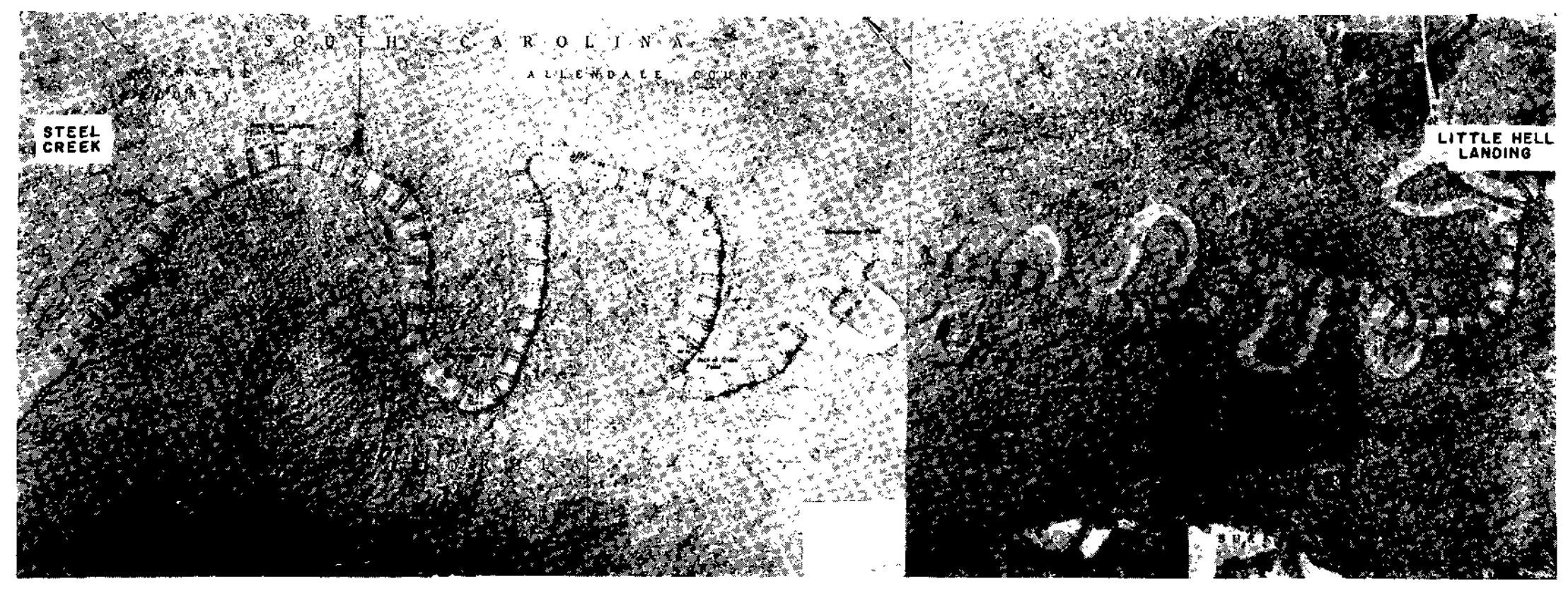

FIGURE I. Savannah River from Steel Creek to Little Hell Landing 
trees and other hardwoods that thrive in this environment. Locally, this area is called the Savannah River Swamp. The streams that drain the SRP site flow through the swamp en route to the river and enter the river at well-defined breaches in the natural levee. The combined flow of Pen Branch and Steel Creek enters the river through a breach in the levee near the southeast corner of the SRP site (Figure 2).

The river flows over the bank into the swamp when river elevations are between 90 and $91 \mathrm{ft}$ above mean sea level (MSL) as measured at the SRP boat dock. When this occurs, Beaver Dam Creek, Four Mile Creek, and the combined Pen Branch-Steel Creek flow do not discharge to the river through their normal breaches in the levee. Instead, the water from these streams flows parallel to the river, past the southeast corner of the SRP boundary, and across approximately four miles of privately owned swamp, known locally as the Creek Plantation Swamp. The water enters the river at Little Hell Landing, an oxbow in the river which is no longer part of the main channel of the river. Figure 3 shows the apparent flow of the SRP streams during river flood stage as determined in a thermal mapping survey in 1961 when five reactors were operating.

The occurrence of swamp flooding is not observed and recorded on a daily basis; however, continuous records of river stage (elevation) at the SRP boat dock indicate that the swamp has been flooded approximately $23 \%$ of the time from 1960 through 1973 . Table 1 shows the average number of days (14-year average) that river stage exceeded $91 \mathrm{ft}$ MSL. The maximum river elevation during this period was $100.8 \mathrm{ft}$ on April 12-15, 1964.

$64 \%$ of the flow over the bank occurs from January through April (Table 2). During swamp flooding in the winter months, the water temperature in the flow path of the effluents through the privately owned swamp is warmer than the main river channel flow, and river fish migrate into the warmer swamp waters. Some portions of Creek Plantation Swamp are accessible by boat. Evidence of set hook fishing lines has been noted. Figure 4 shows one such location near the Steel Creek Boat Landing with a line suspended between trees containing a number of set-hook fishing lines. The Steel Creek Landing is accessible to the public from S. C. Highway 125 by a county road that crosses the Creek Plantation.

At times of the year when the swamp is not flooded, fishermen cross the Creek Plantation to launch boats in the Savannah River at the Steel Creek Landing (Figure 5), near the western boundary of the Creek Plantation Swamp. 


\section{TABLE 1}

River Overflow To Swamp Between 1960 and 1973

Avg Days Per Year

$\begin{array}{lc}\text { Month } & \text { that River Stage } \\ \text { January } & 13 \\ \text { February } & 12 \\ \text { March } & 16 \\ \text { Apri1 } & 13 \\ \text { May } & 7 \\ \text { June } & 6 \\ \text { July } & 3 \\ \text { August } & 1 \\ \text { September } & 2 \\ \text { October } & 2 \\ \text { November } & 1 \\ \text { December } & \frac{8}{44}\end{array}$

\section{TABLE 2}

Swamp Flooding Summary For 1960 to $1973^{\alpha}$

Avg days flooded/year

Avg $\%$ of time flooded

Total days flooded in 14 years

1179

Months of maximum flooding

January through Apri1

Maximum recorded flood level

a. Flooding based on number of days river level exceeded $91 \mathrm{ft}$. 


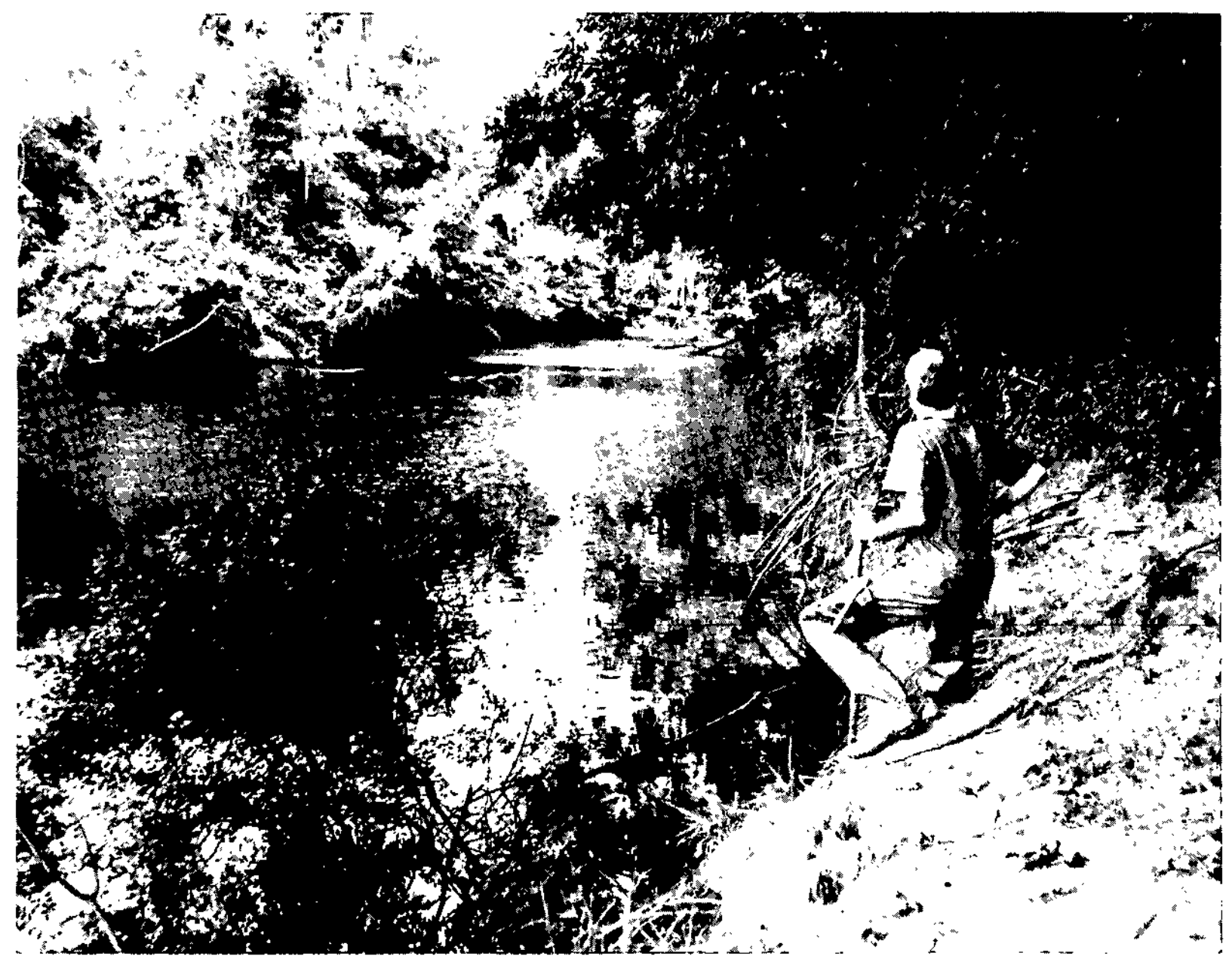

FIGURE 2. Steel Creek Mouth 


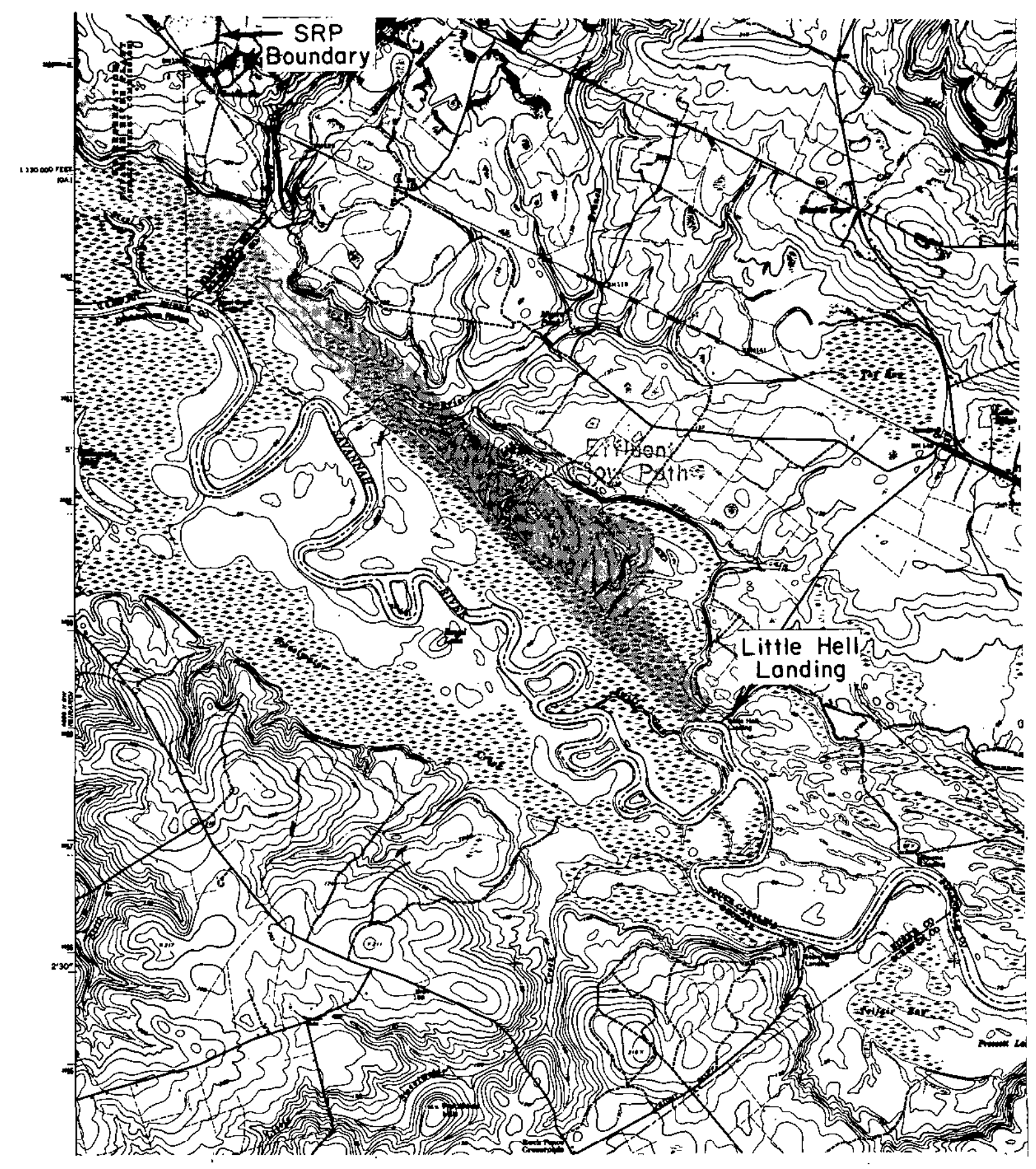

FIGURE 3. SRP Thermal Effluent Flow during Swamp Flooding 


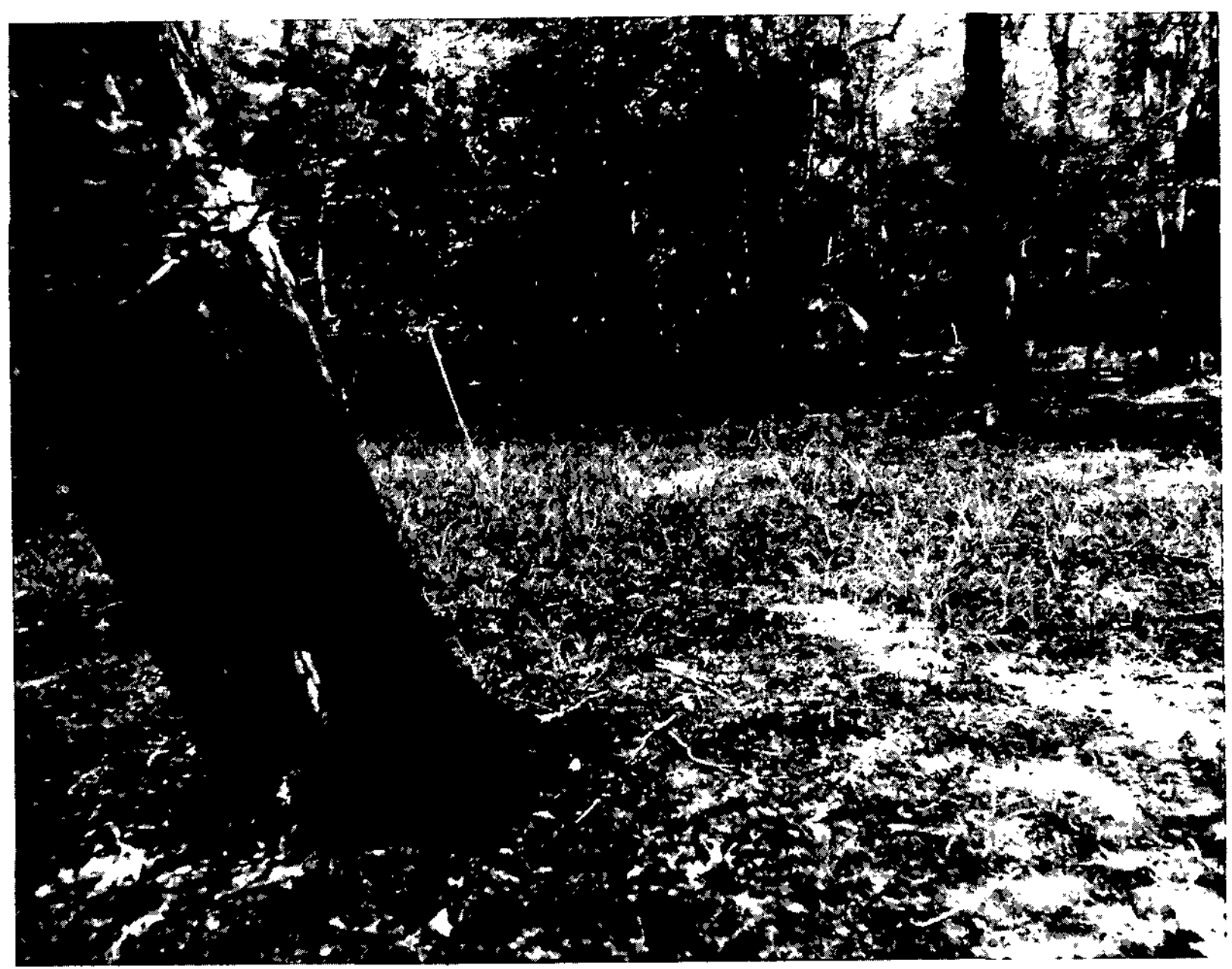

FIGURE 4. Creek Plantation Swamp Near Steel Creek Landing 


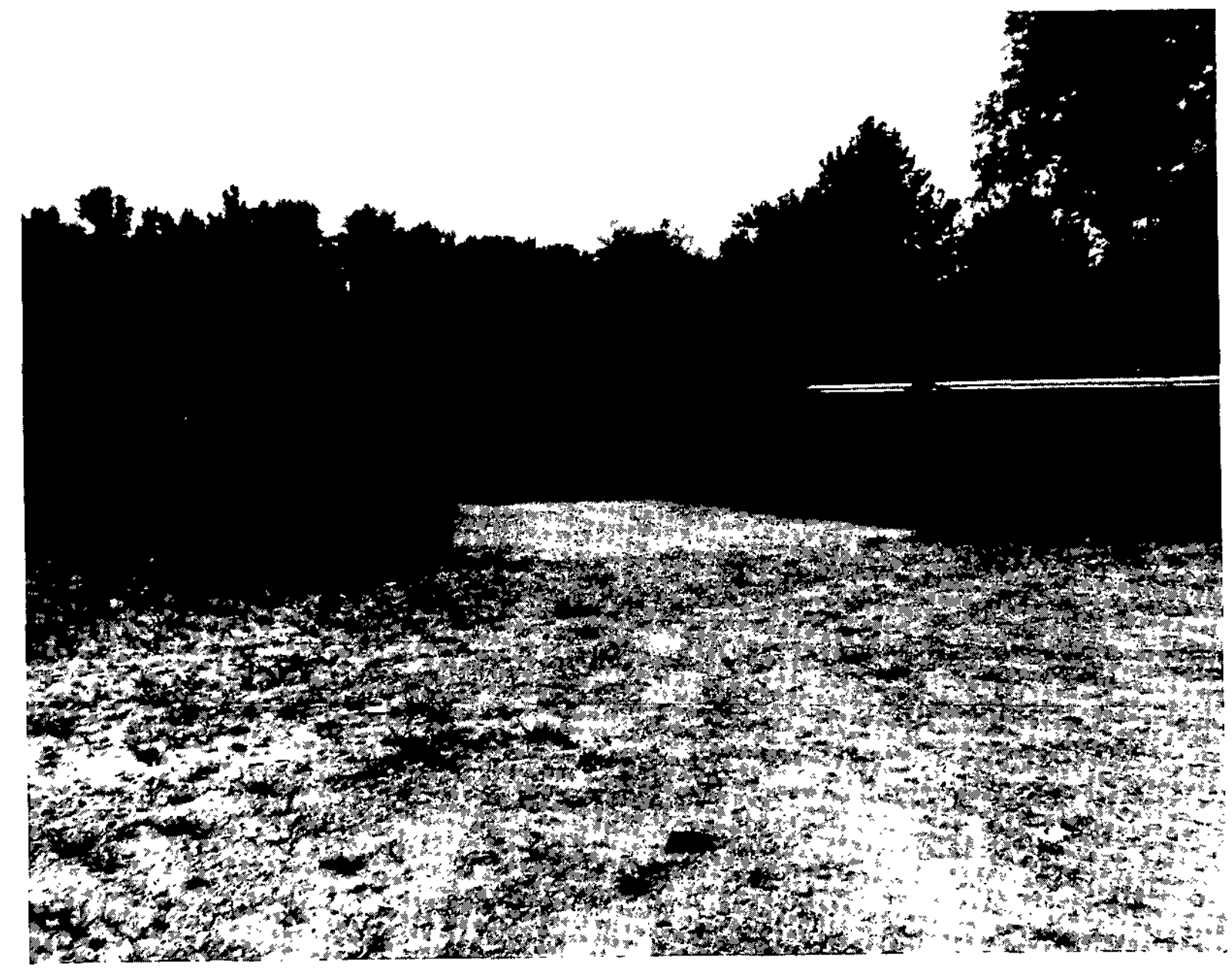

FIGURE 5. Steel Creek Landing, Looking Toward River 
When the swamp is flooded, the velocity of water flow in the swamp is much lower than in the main river channel because of the width (2000 to $3000 \mathrm{ft}$ ) and because of flow restrictions caused by dense understory growth and a large population of hardwood trees (Figures 6 and 7). At the margin of the flood plain, there is a depressed channel in the swamp (Figure 8) through which most of the SRP effluents flow during flood stage and emerge at a slough at Little Hell Landing (Figure 9).

As the SRP streams enter the on-site swamp, coarser sediments are deposited and form deltas or fluvial fans in the swamp.

Figure 10 is an aerial photo made in 1966 of the Steel Creek delta and entry to the on-site swamp. Also shown in this photo is the normal creek flow path across the on-site swamp to the river and Steel Creek Landing (on Creek Plantation Swamp property). The Steel Creek delta on SRP property is now well-stabilized with plant cover and is not expected to be subject to major erosion by flood waters. Finer sediments, consisting mainly of kaolin clay, are deposited further downstream in the swamp during flood stage, both on the SRP site and in Creek Plantation Swamp. The radioactivity in the swamp, discussed in a later section of this report, is sorbed or bound by natural ion-exchange processes on these sediments. From these sediments, radioactivity (mainly ${ }^{137} \mathrm{Cs}$ ) is taken up by vegetative growth, as discussed in a later section of this report. The sediments, once deposited, are relatively immobile because of the low water velocity in the swamp during periods of flooding and overlayering of later sediment deposits.

\section{HISTORY OF RADIOACTIVITY IN THE SAVANNAH RIVER SWAMP}

In 1958 , an aerial radiation survey by the U. S. Geologic Survey revealed no unusual radioactivity in the Savannah River Swamp, either on-site or off-site. ${ }^{1}$ In 1959 , a ground observer noted that SRP effluents apparently overflowed the road to Steel Creek Landing on the Creek Plantation Swamp. This was observed as fog rising from warmer than natural water in the swamp on a cold winter day. In 1961, the SRP effluent flows were thermally mapped during a period of swamp flooding when five SRP production reactors were in operation and four reactors were discharging heated water to the swamp. The fifth discharged to Par Pond, which overflows into Lower Three Runs Creek. This survey indicated that SRP effluents were confined to the swamp during flood stage and flowed southeastward parallel to the swamp margin, entering the Savannah River at Little Hel1 Landing approximately 4 miles from the SRP site boundary (Figure 3). A small number of vegetation samples taken at that time showed the presence of trace levels of ${ }^{137} \mathrm{Cs},{ }^{60} \mathrm{Co}$, and short-lived fission products, such as ${ }^{144} \mathrm{Ce},{ }^{103} \mathrm{Ru},{ }^{106} \mathrm{Ru}$, and ${ }^{95} \mathrm{Zr}-{ }^{95} \mathrm{Nb}$. 


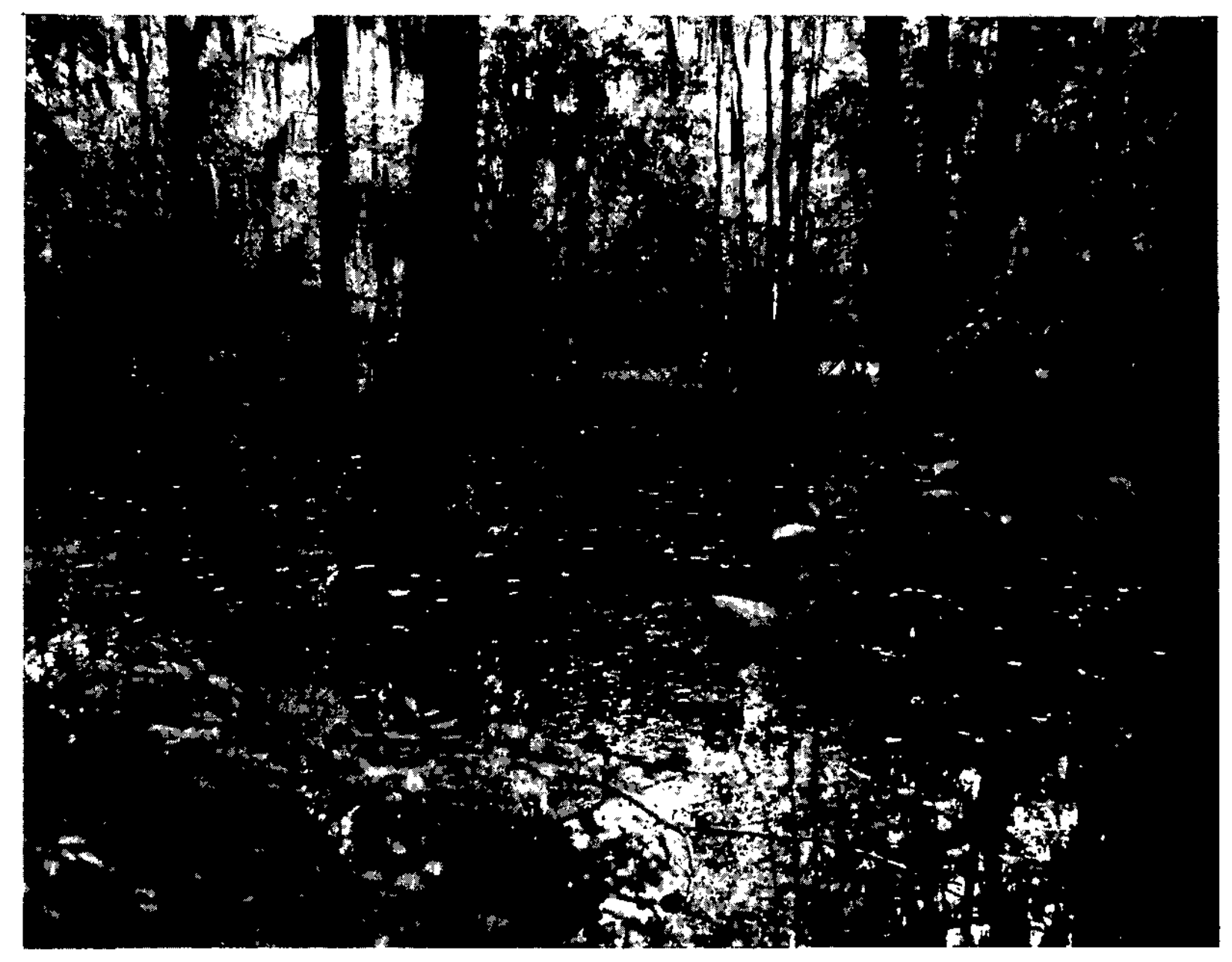

FIGURE 6. Standing Water in Creek Plantation Swamp 


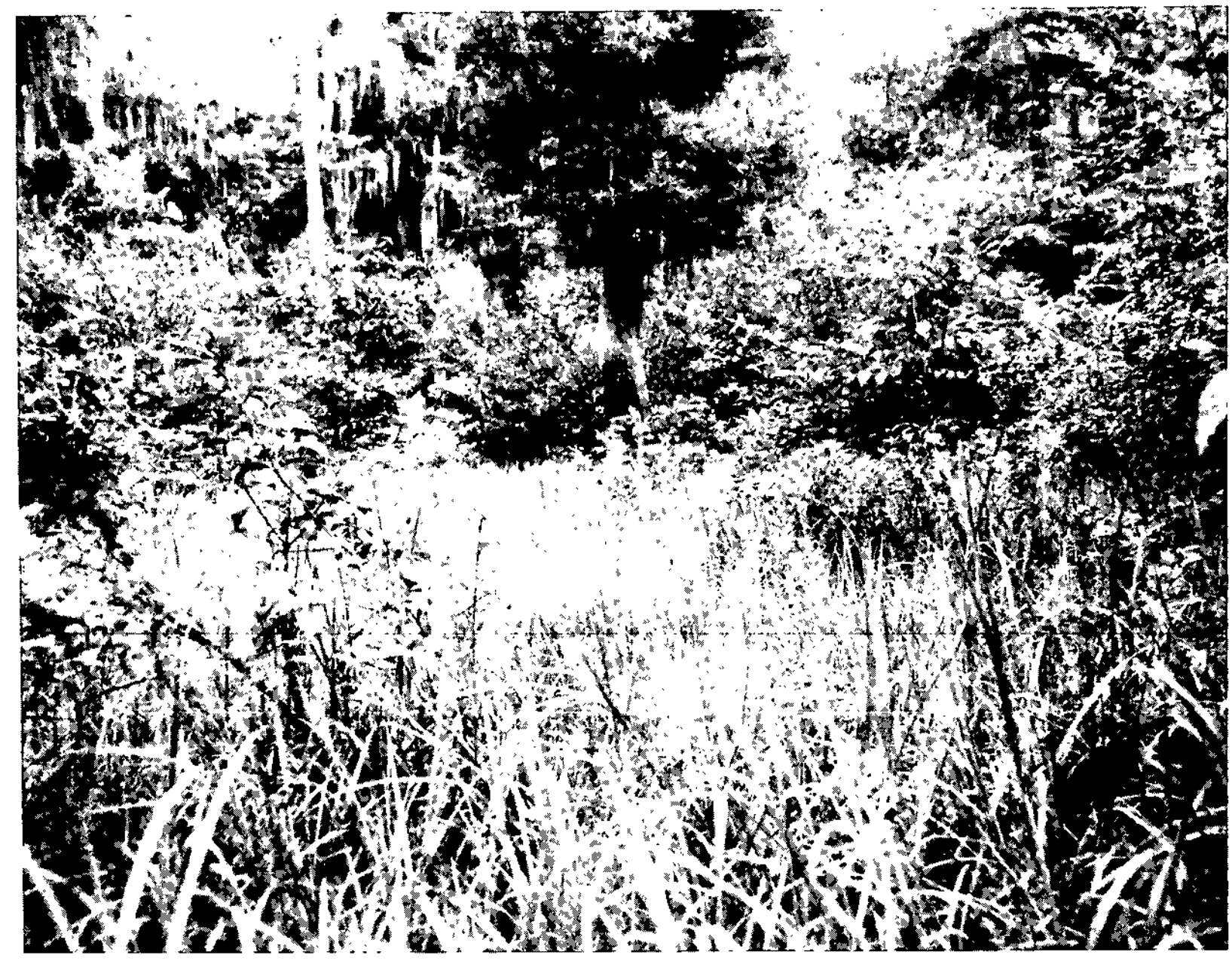

FIGURE 7. Creek Plantation Swamp near Steel Creek Landing 


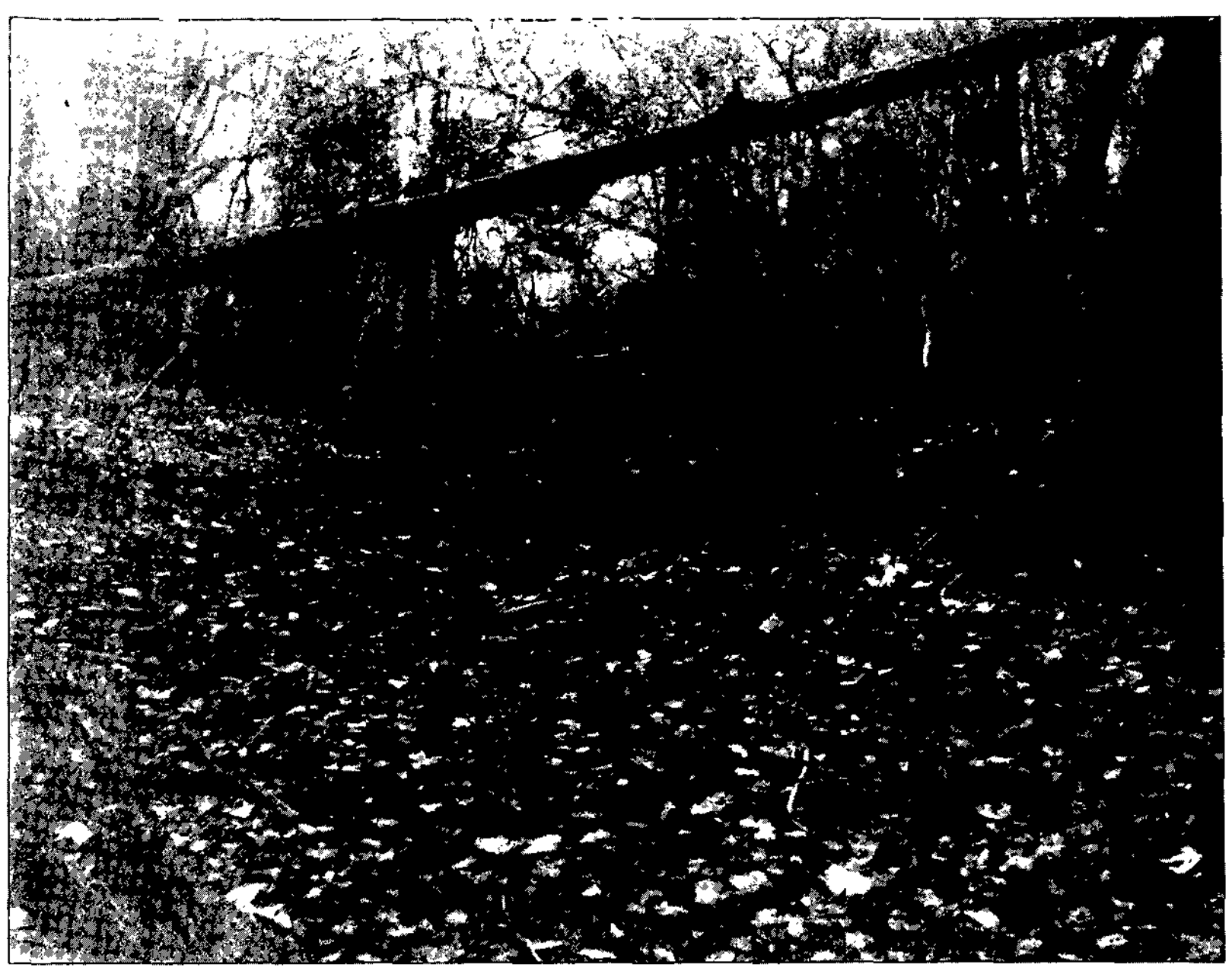

FIGURE 8. Depression in Creek Plantation Swamp 


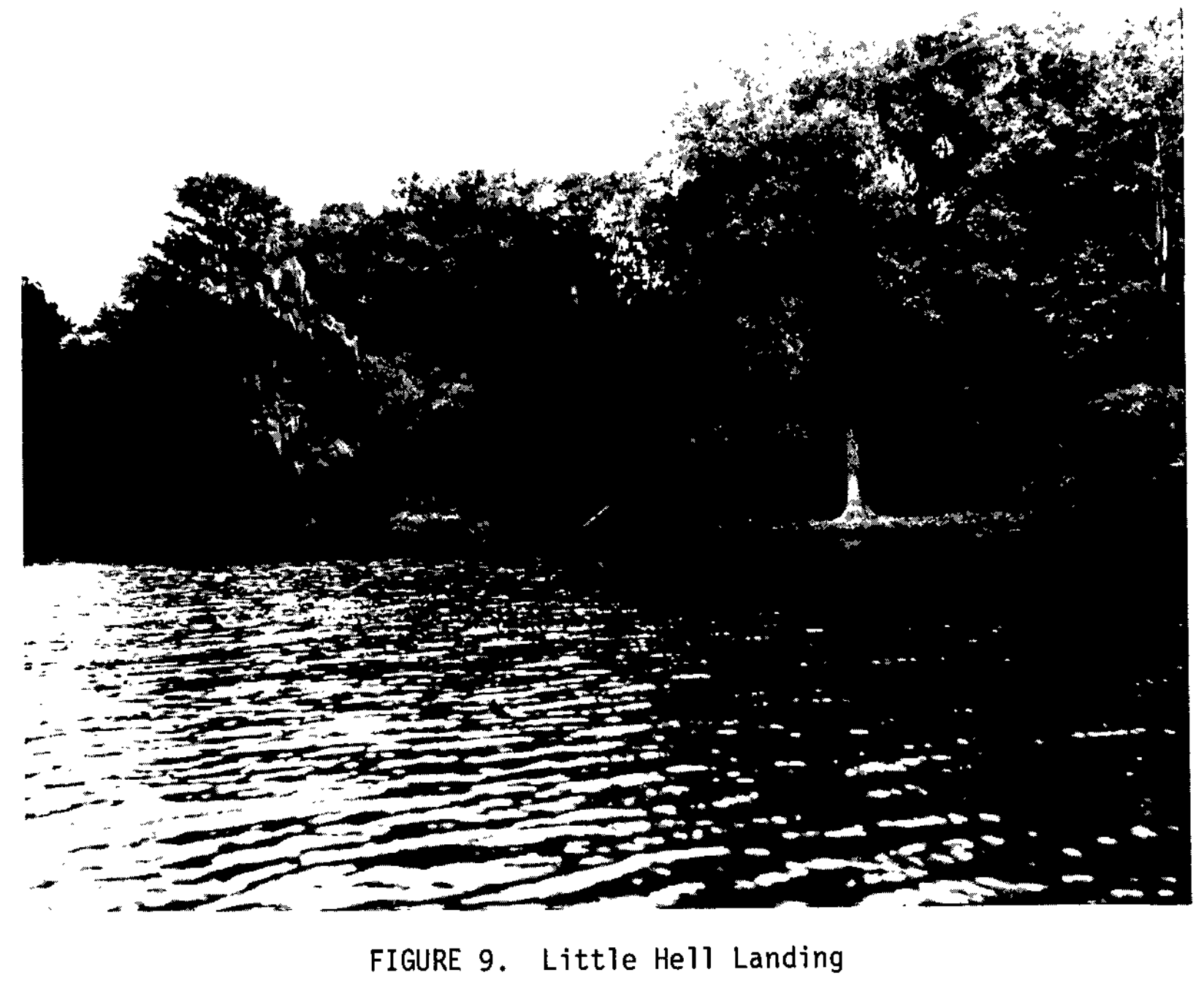




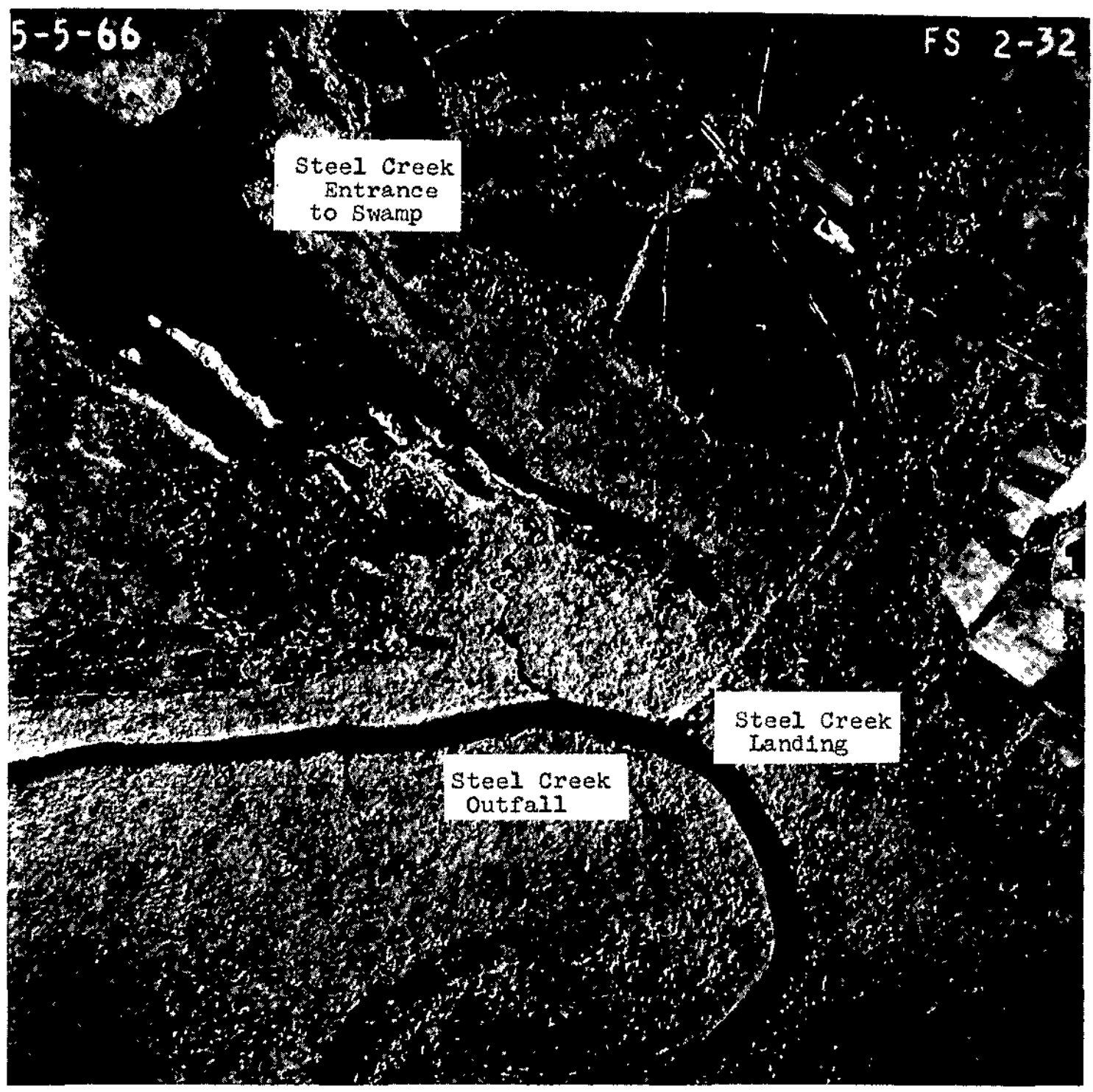

FIGURE 10. Steel Creek, Delta and Steel Creek Landing (Aerial Photograph) 
An EG\&G aerial radiological survey made in 1969 over the Savannah River Swamp at locations both upstream and downstream from SRP detected no off-site radiation attributable to plant operations. This survey, made along a single flight line, was made with a fixed-wing aircraft flying at an elevation of $500 \mathrm{ft}$ above the ground. The detection system was an array of fourteen uncollimated $4 \times 4-i n$. NaI crystals. More extensive EG\&G aerial radiological surveys made in 1971 and 1972 with similar equipment in a different flight line showed radiation exposure levels in the Creek Plantation Swamp up to $42 \mu \mathrm{R} / \mathrm{hr}$ (368 mR/year) above background. The natural radiation exposure level in the general swamp area was $8 \mu \mathrm{R} / \mathrm{hr}$.

Ground surveys made by the Health Physics Environmental Monitoring Group in several areas of the swamp in 1971 and 1972 confirmed the 1971-1972 aerial survey by EG\&G. The maximum gamma exposure rates found in the 1971 and 1972 EGEG aerial survey (corrected for background) in the Creek Plantation Swamp were $368 \mathrm{mR} / \mathrm{yr}$. Continuous exposure to this radiation field would result in a dose of $74 \%$ of the $500 \mathrm{mrem} /$ year maximum permissible dose to an off-site individual as specified in AEC Manual Chapter 0524 and Code of Eederal Regulations, Title 10, Part 20. The occupational dose limit specified in these regulations is $5000 \mathrm{mrem} / \mathrm{year}$.

In 1974 , EGGG made another aerial survey at lower flight speed using a helicopter and more-advanced instrumentation capable of measuring dose rates for each gamma-emitting radionuclide. This survey revealed exposure rates ranging from 30 to about $460 \mathrm{mR} /$ year above background in one-third of the five-square-mile Creek Plantation Swamp. (Figure 11 shows isodose contours for ${ }^{137} \mathrm{Cs}$, the predominant radionuclide found in the swamp.) Recent ground surveys by the Health Physics Environmental Monitoring Group in ten selected swamp transects verified the EGqG aerial survey. (Figure 12 shows locations of the transects.) 


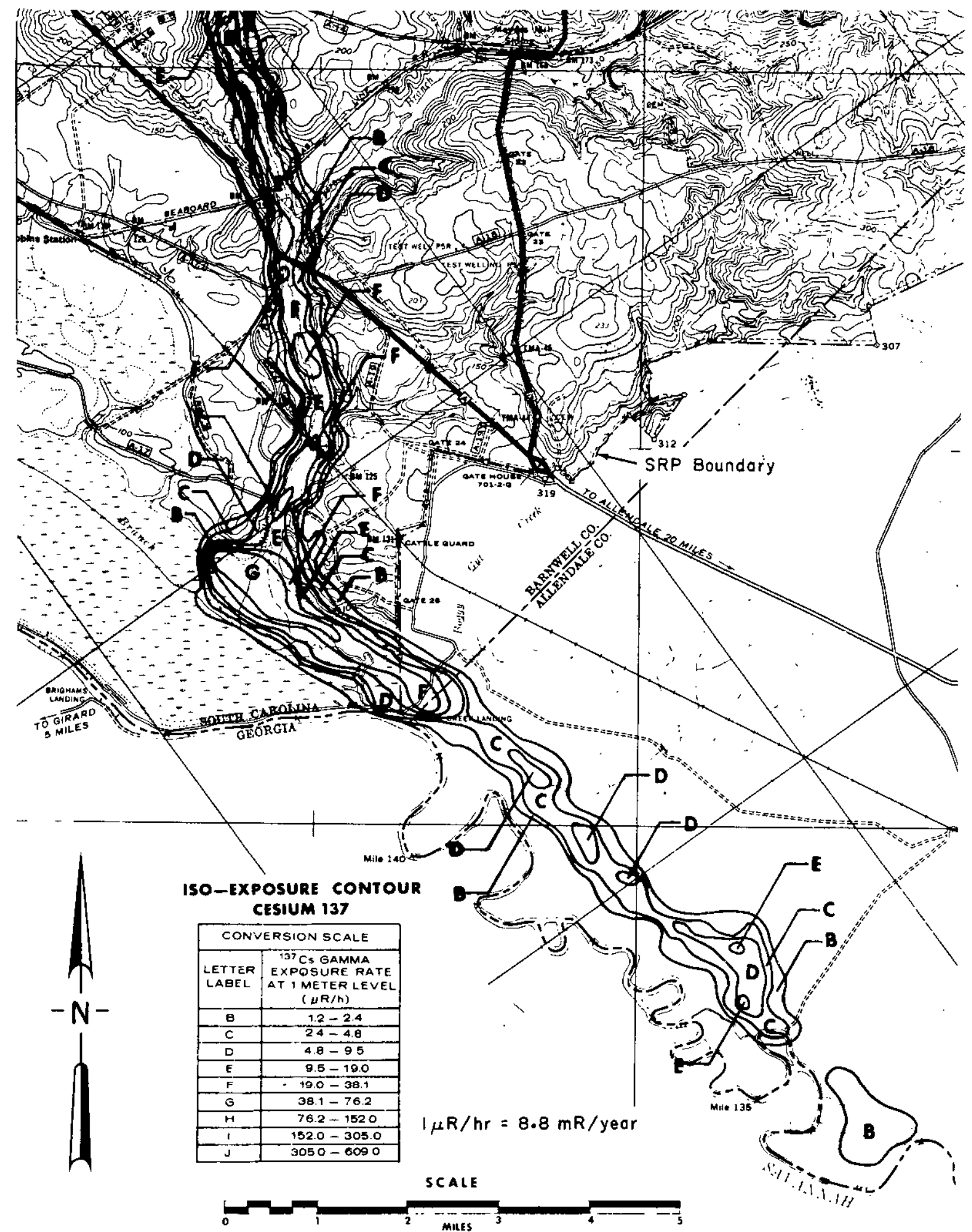

FIGURE 11. Isodose Contours for Cesium-137 from 1974 EG\&G Aeroradiographic Survey 


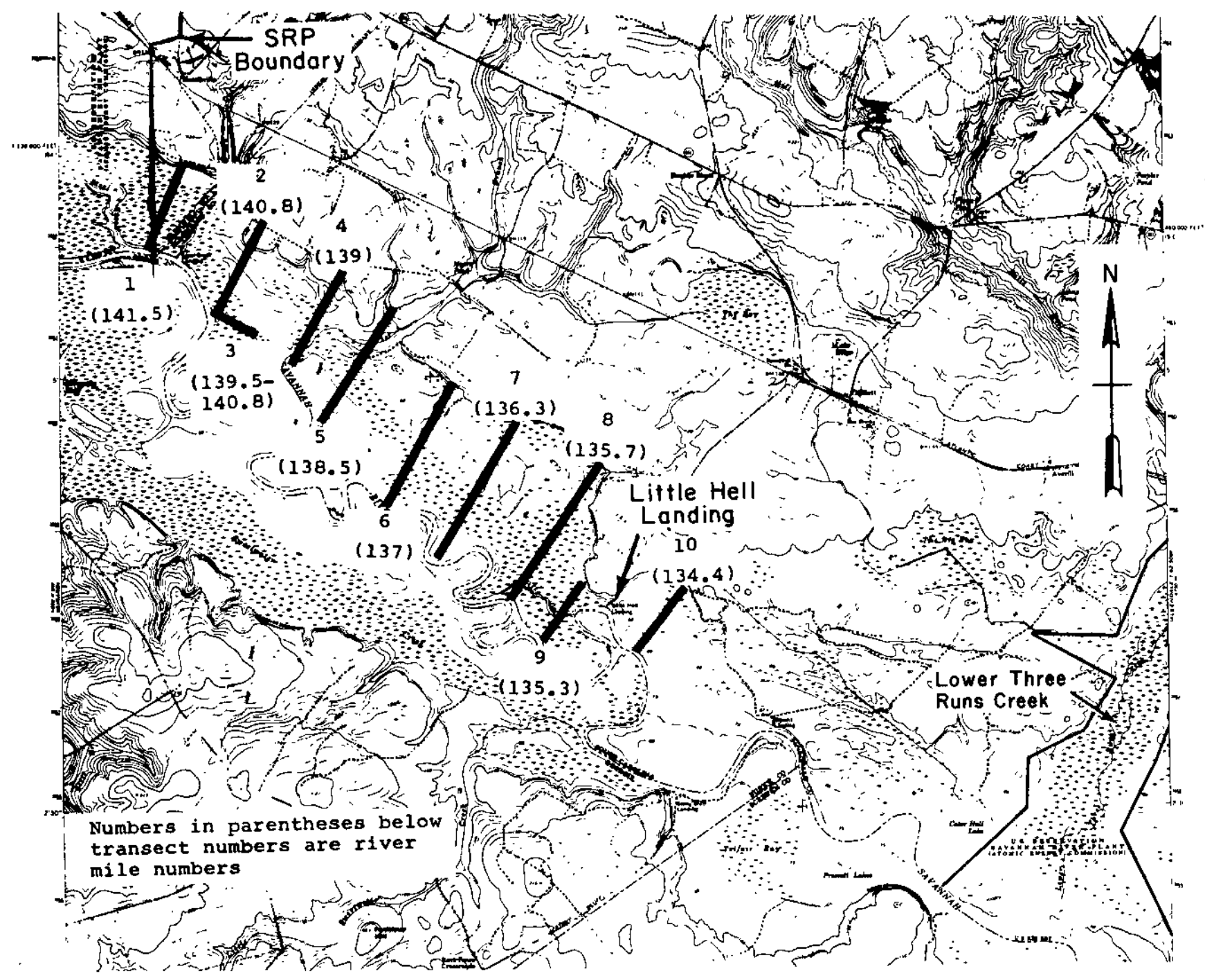

FIGURE 12. 1974 Ground Survey Transects 
SOURCE OF CESIUM-137 IN THE SAVANNAH RIVER SWAMP

The radioactivity in the swamp, predominantly ${ }^{137} \mathrm{Cs}$, originated from discharge to on-site streams (primarily Steel Creek) from reactor fuel storage facilities in plant production reactors during the 1960 's. Figure 13 shows ${ }^{13^{7}} \mathrm{Cs}$ discharges from all reactors by year as measured at the point of release in the reactor areas. The same data are shown in tabular form in Table 3 by individual reactors by year. An additional $39 \mathrm{Ci}$ of ${ }^{137} \mathrm{Cs}$ was discharged from the separations areas, which discharge to Four Mile Creek. Thus, a total of about $500 \mathrm{Ci}$ of ${ }^{137} \mathrm{Cs}$ has been discharged to all plant streams over the $20+$ years of plant operation. Of this total, $267 \mathrm{Ci}$ (53\% of total) was discharged to Steel Creek between 1961 and 1973.

\section{TABLE 3}

Cesium Releases by Reactor Areas, $\mathrm{Ci}$

$\begin{array}{lcrrrrr} & R & P & L & K & C & \text { Total } \\ 1961 & 10.3 & 4.2 & 1.0 & 1.8 & 1.7 & 19.0 \\ 1962 & 13.2 & 13.7 & 1.3 & 4.6 & 4.8 & 37.6 \\ 1963 & 83.4 & 9.0 & 0.9 & 3.3 & 0.7 & 97.3 \\ 1964 & 47.1 & 45.6 & 7.7 & 5.6 & 0.7 & 106.7 \\ 1965 & - & 29.8 & 1.3 & 2.5 & 0.3 & 33.9 \\ 1966 & - & 35.7 & 0.9 & <0.1 & - & 36.6 \\ 1967 & - & 45.1 & 0.7 & 0.5 & 0.7 & 47.0 \\ 1968 & - & 40.9 & 0.2 & 0.1 & 0.1 & 41.3 \\ 1969 & - & 13.1 & 3.4 & -3 & 3.5 & 20.0 \\ 1970 & - & 7.7^{a} & 3.2 & - & 9.7 & 20.6 \\ 1971 & - & 1.3 & - & - & 0.2 & 1.5 \\ 1972 & - & 0.2 & - & <0.1 & -c & 0.2 \\ 1973 & - & 0.4 & - & \leq 0.1 & 0.1 & 0.5 \\ \text { T0TAL } & 154.0 & 246.7 & 20.6 & 18.4 & 22.5 & 462.2\end{array}$

a. Sand filter operation started in P Area on October 1970.

$b$. Sand filter operation started in K Area on December 1969.

c. Sand filter operation started in C Area on April 1972. 


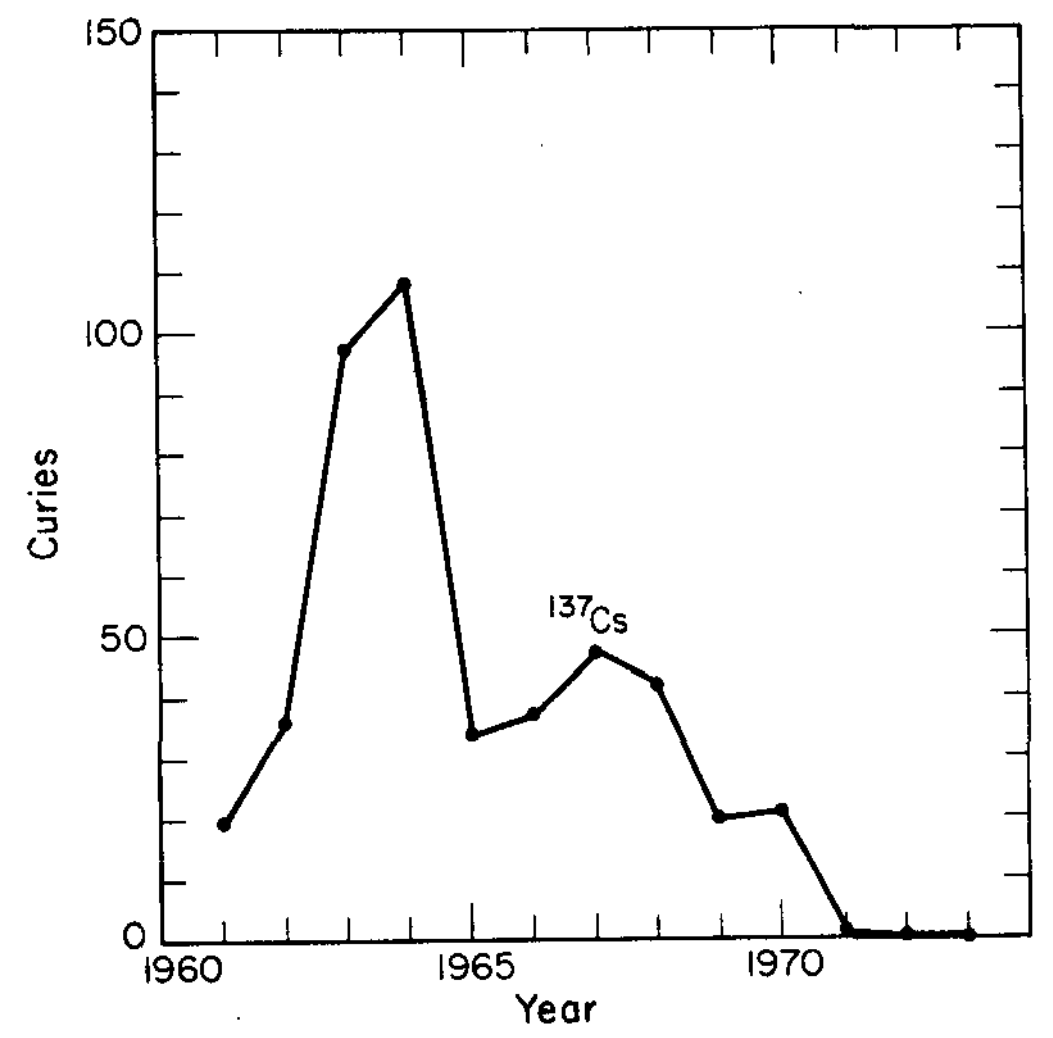

FIGURE 13. Reactor Releases of Cesium-137

$-26-$ 
Leaking and failed fuel elements were the source of the ${ }^{137} \mathrm{Cs}$ in the fuel storage basins in all reactor areas. Failed production reactor fuel elements were placed in failed fuel element containers in the fuel storage basins. These containers are sealed against water leakage, but gases are vented to the atmosphere through filters and charcoal absorbers. This transfer to failed fuel element containers was done underwater, and in the process, some fission products were released to the fuel storage basin water. Before the shutdown of $\mathrm{R}$ Reactor in 1964, leaking and failed production fuel element experience was higher than in the other reactor areas. Experimental zirconium-clad, uranium oxide fuels (test of fuels for the Heavy Water Components Test Reactor) irradiated in $\mathrm{R}$ Area and stored in the fuel basin in $P$ Area were the major source of releases from $P$ Area starting in 1964. These experimental fuels were stored in 225 vented cans in P Area until late 1968 and early 1969, when they were moved to the Receiving Basin for Off-Site Fuels (RBOF) in 200-H Area. The cans of experimental fuel elements that were leaking fission products were isolated in long underwater tubes to prevent leakage of ${ }^{137} \mathrm{Cs}$ and other fission products. They remain stored in RBOF.

The reduction of $R$-Area releases following shutdown of $R$ Reactor in 1964 is evident in Table 3. L Reactor, shut down in 1968 , continued to be a source of activity release through 1970 because the fuel storage basin was used to store irradiated fuels for two years following the shutdown.

Heat exchangers were installed in the reactor areas in 1963 to permit recirculation of fuel storage basin water. Releases of radioactivity following 1963 occurred as a result of periodic purging of fuel storage basin water to maintain water clarity for underwater operations. Mobile deionizers were used to remove some of the radioactivity during the purges. In the late 1960's and early $1970^{\prime} \mathrm{s}$, sandfilters were installed in the three remaining operating reactors to maintain water clarity and to remove radioactivity associated with filterable material suspended in basin water. The sharp drop in effluent releases of ${ }^{13{ }^{7} \mathrm{Cs} \text { in these }}$ reactor areas following the sandfilter installation is clearly evident in Table 3 . In 1972 and $1973,0.2 \mathrm{Ci}$ and $0.5 \mathrm{Ci}$ of ${ }^{1{ }^{3} \mathrm{Cs}}$ were released during periodic purges of fuel storage basin water through deionizers to SRP streams. These purges were necessary to maintain tritium-oxide concentrations within operating limits.

The concentration of ${ }^{137} \mathrm{Cs}$ in on-site streams has never exceeded $3.0 \%$ of the concentration guide of $2 \times 10^{-5} \mu \mathrm{Ci} / \mathrm{ml}$ as specified in AEC Manual Chapter 0524 for uncontrolled areas. The release of $500 \mathrm{Ci}$ is only about $0.2 \%$ of the amount that could have been released and remain within the drinking water guides. Consumers of untreated river water downstream of the SRP site would 
receive only a small fraction of the 500-mrem dose 1 imit for individuals even if releases at the concentration guide value had occurred.

${ }^{137} \mathrm{Cs}$ was also discharged to on-site seepage basins during the 1960's. A total of $308 \mathrm{Ci}$ (1960-1973) went to seepage basins as compared to $500 \mathrm{Ci}$ to effluent streams. The radiocesium in the seepage basins has migrated no more than a few feet in the soil and will decay to innocuous levels before reaching a surface stream. Releases of cesium to on-site basins are expected to have negligible effect on the off-site environment.

The same ion-exchange phenomenon which immobilizes cesium near the bottoms of seepage basins occurs with cesium released to effluent streams. Much of the cesium becomes sorbed or bound to the sediments. Of the $500 \mathrm{Ci}$ released to streams, only $290 \mathrm{Ci}$ have been measured in transport at SRP Road A (S.C. Road 125), the last stream sampling point before the streams enter the Savannah River Swamp. On 1 y $90 \mathrm{Ci}$, or $18 \%$ of the total released, has been measured in transport in the Savannah River, downstream at the U. S. Highway 301 bridge (Table 4).

TABLE 4

Cesium-137 Transport (1961-1973)

Cumies

Released $\quad 500$

Road A 290

River at Highway $301 \quad 90$

Figure 14 shows the release of ${ }^{137} \mathrm{Cs}$ to SRP streams. $348 \mathrm{Ci}$ have been released to streams that discharge to the swamp upstream from the Creek P1antation Swamp. Although R Reactor has discharged $154 \mathrm{Ci}$, only $43 \mathrm{Ci}$ have been measured downstream from the Par Pond Dam in Lower Three Runs Creek at Pattersons Mill Bridge. 


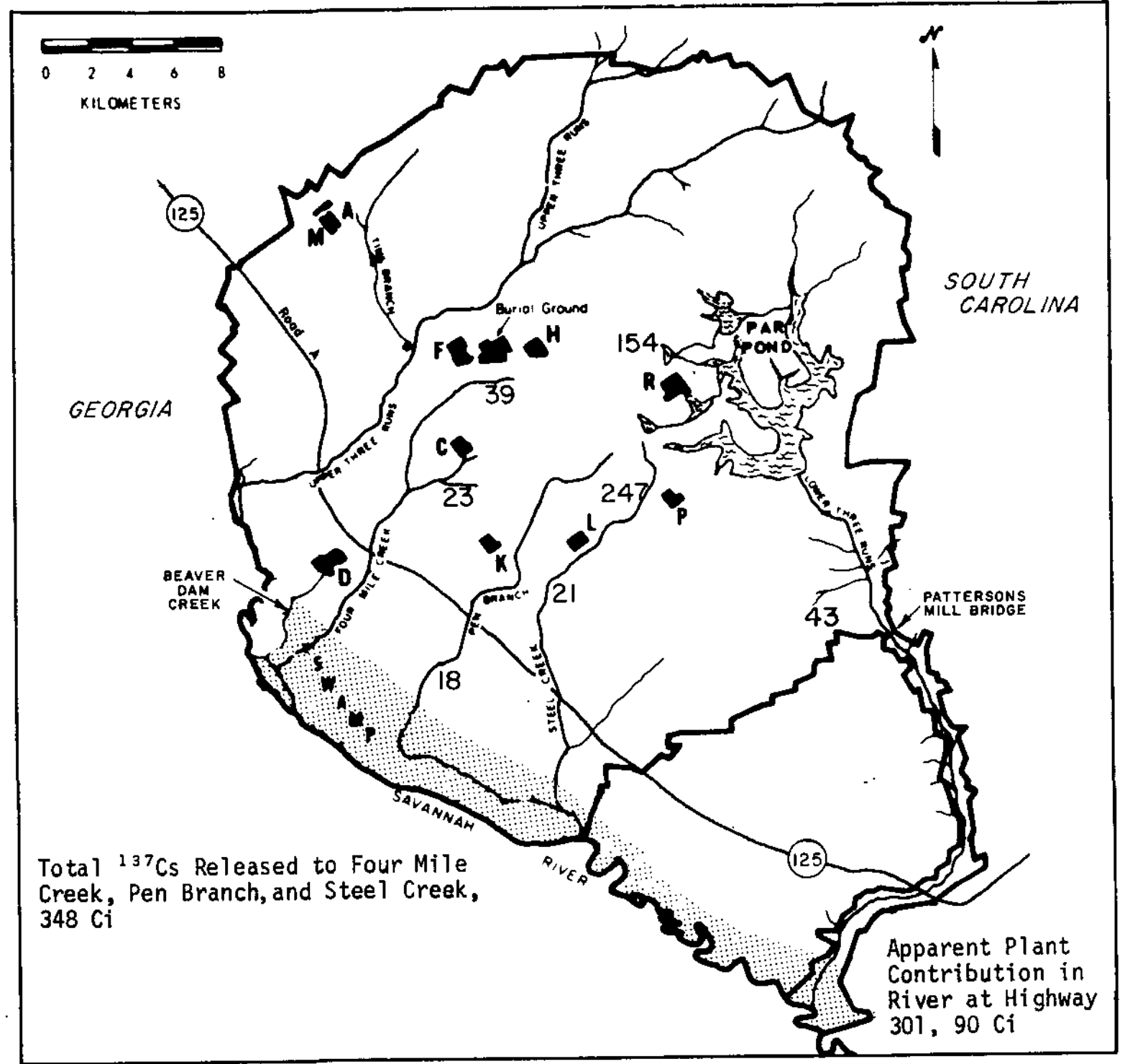

FIGURE 14. SRP Map Showing Cesium Releases to Each Effluent Stream 


\section{SWAMP SURVEYS}

The location of radioactivity, radiation levels, and concentrations of radioactivity in sediments and biota are based on the four most recent surveys ( 2 aerial surveys and 2 ground surveys) described below:

- July 1971 EG\&G Aerial Survey. This survey was made of an area about $\frac{1}{4}$ mile wide and 25 miles long extending from Beaver Dam Creek to the confluence of Lower Three Runs Creek with the Savannah River. The survey was made with NaI detectors in a fixed-wing aircraft flying at an altitude of $500 \mathrm{ft}$ with a field of view of about $1200 \mathrm{ft}$ in diameter. Data were in the form of gross gamma count rates, converted to exposure rates $(\mu \mathrm{R} / \mathrm{hr})$ at $3 \mathrm{ft}$ above the ground.

- May-June 1972 Health Physics Ground Survey. This survey was made along three transects of the Savannah River Swamp between Steel Creek and Little Hell Landing. The transects began at the river and terminated on high ground bordering the swamp. Vegetation and soil samples were obtained for radioanalysis of each of 18 marked locations, and thermoluminescent dosimeters (TLD's) measured gamma radiation dose rates.

- Jine 1974 EG\&G Aerial Survey. This survey was made with a U. S. Air Force helicopter flying at an altitude of $500 \mathrm{ft}$. The detectors consisted of two arrays of $205 \times 2$-in. NaI crystals. Gamma spectra were recorded every $3 \mathrm{sec}$, and gross gamma count rate was recorded every $1 \mathrm{sec}$ for a field of view of about $1000 \mathrm{ft}$ in diameter. On-board navigation systems processed signals from two radio transponders mounted in nearby fire towers; positioning accuracy was within $10 \mathrm{ft}$ of a given point on the ground. A mobile ground-based computer system was used to process tape-stored data from the aerial survey.

- July-August 1974 Health Physics Ground Survey. This survey was similar to the 1972 survey but was enlarged to include 10 transects (Figure 12) of the swamp. On-the-spot gross gamma exposure rates at $3 \mathrm{ft}$ above the surface were made with portable gamma scintillometers (Technical Associates, Mode1 FS-11). In addition to vegetation and soil sampling (cores) and TLD measurements, animal wildlife (ducks and fish) were obtained for radioanalysis. As in 1972 survey, sampling points were marked for future surveys, and photographs were made of representative swamp habitats. 


\section{GAMMA EXPOSURE RATES IN THE SWAMP}

The maximum gamma exposure rate detected in the off-site swamp by the 1974 aerial survey was found at the plant perimeter near Steel Creek and was approximately $460 \mathrm{mR} /$ year (Table 5), corrected for natural background. The gamma radiation was primarily from ${ }^{137} \mathrm{Cs}$ (Figure 11 shows isodose curves for ${ }^{137} \mathrm{Cs}$ ). The offsite swamp area containing ${ }^{137} \mathrm{Cs}$, as shown in Figure 11 , is 1.9 square miles or approximately 1235 acres. This is approximately one-third of the five-square-mile swamp between the SRP boundary and Lower Three Runs Creek. ${ }^{60}$ Co was detected only in a narrow; intermittent strip along the centerline of the maximum ${ }^{13} \mathrm{Cs}$ deposition. This strip is about $3 \mathrm{miles}$ long and averages about $800 \mathrm{ft}$ wide (a total area of about 0.5 square miles or 320 acres). In this narrow strip, the ${ }^{60}$ Co contributes 20 to $40 \%$ of the gamma exposure rates. No other man-made gamma emitters were detected in the aerial survey.

Table 5 indicates good agreement between the 1971 and 1974 aerial surveys and between the 1974 aerial surveys and the 1974 ground survey, with the exception of a, small area detected by portable scintillometer about 1 mile northwest of Little Hell Landing during the 1974 ground survey. (Appendix A). A maximum dose rate of $67 \mu \mathrm{R} / \mathrm{hr}$ ( $~ 590 \mathrm{mR} /$ year) above background was detected on the transect at River Mile 138.5 (Figure 15) on a small strip of land (several yards wide) between two sloughs containing standing water. This exposure rate was not observed in the 1974 aerial survey because of limited resolution of the detector system for small area sources and is not used in calculations of dose to a hypothetical individual. The slight increase in exposure rates (Table 5) between the 1971 and 1974 aerial surveys could be attributed to a more comprehensive survey and a more-sensitive measuring technique used in 1974 and/or to slight shifting of sediments in the swamp.

Thermoluminescent dosimeter measurements of gamma dose rates on three transects of the swamp in 1974 were generally slightly higher than in 1972 (Appendix B). The increase could be attributed to lack of precise repositioning of the dosimeters and/or a slight shifting of sediments in the off-site. swamp. Regardless of either event, it appears that the radioactivity in the sediments is relatively immobile and is unlikely to have any effect on the river. Discharges from a11 SRP facilities are maintained at the lowest practical level and are monitored on a continuous basis to assure that off-site releases are minimized. The swamp will be monitored periodically to provide a basis for continued evaluation. 


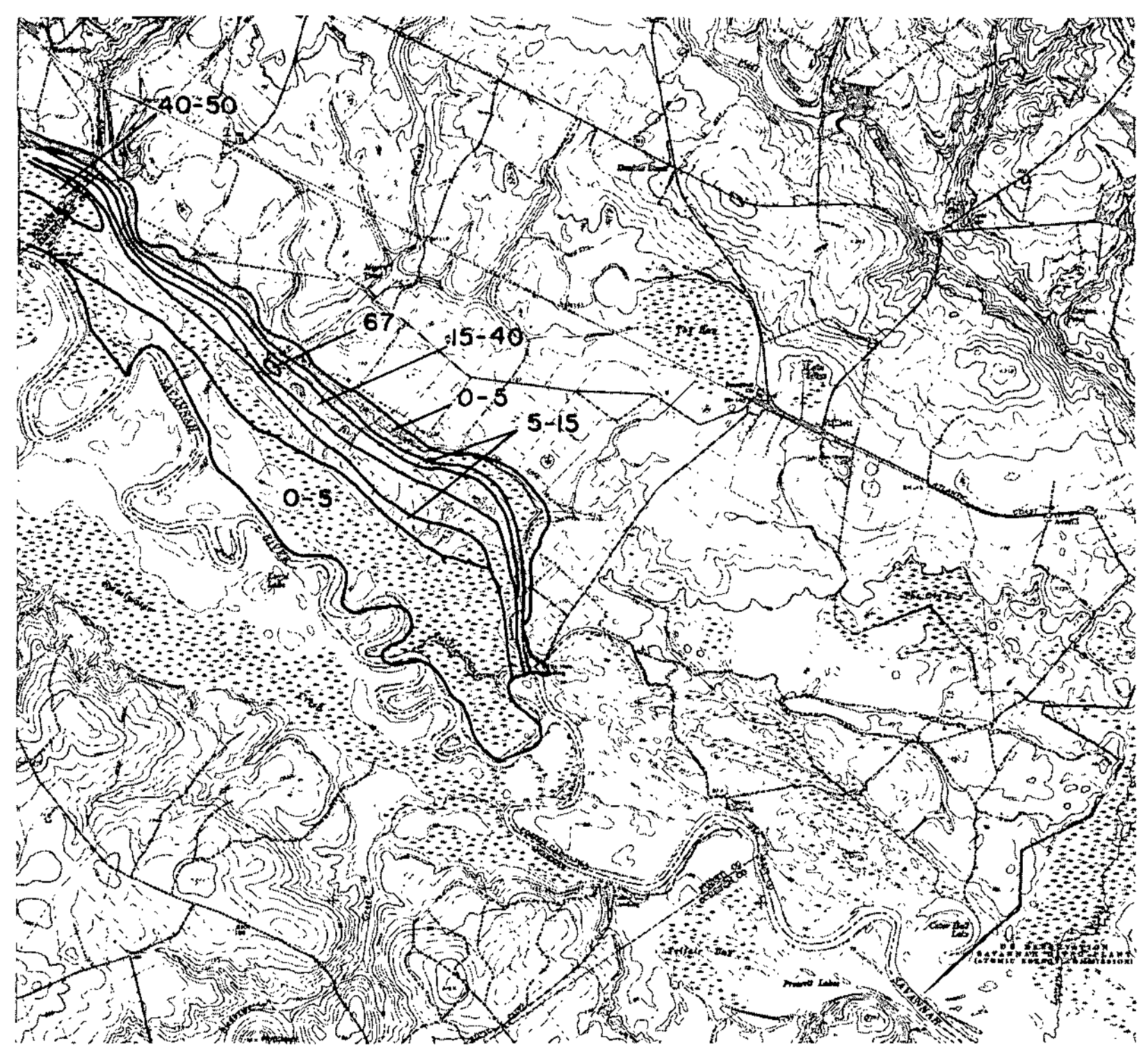

FIGURE 15. Isodose Contours from 1974 Ground Survey (Exposure Rate at $3 \mathrm{ft}, \mu \mathrm{R} / \mathrm{hr}$ ) 
TABLE 5

Maximum Exposure Rates at 3 Feet Above Ground

P1ant perimeter near Steel Creek

1 mile NW of Little He11 Landing

Uncontaminated Swamp (natura1)

Fal1 Line Outcrops (natural)

\begin{tabular}{lll}
\multicolumn{2}{c}{ Exposure } & Rates in $\mu R / h r$ (mR/year) \\
\hline EG\&G- & EG\&G- & Ground Survey- \\
$1971-1972$ & 1974 & 1974 \\
$8-42^{a}$ & $26-53^{a}$ & $47^{a}$ \\
$(70-368)$ & $(228-464)$ & $(412)$ \\
& & \\
$4-15^{a}$ & $13-26^{a}$ & $67^{a}$-sma11 area \\
$(35-140)$ & $(114-228)$ & $(587)$ \\
& & $35^{\alpha}$-max other
\end{tabular}

(307)

$8-10$

$(70-88)$

$\begin{array}{llc}4-8 & - & 8-10 \\ (35-70) & & (70-88) \\ & & - \\ & & 53-55 \\ & (460-480) & \end{array}$

a. Corrected for natural background.

of the five-square-mile area of swamp between the plant perimeter and Lower Three Runs Creek, approximately one-third of the area had exposure rates (above background) ranging from 30 to $460 \mathrm{mR} /$ year. The remainder of the swamp was at natural background levels of 70 to $88 \mathrm{mR} /$ year. In comparison, natural gamma radiation exposure rates along Fall Line outcrops of granite and other metamorphic rock (near Evans, Ga., 27 miles northwest of SRP and also in northern Aiken County, S. C.) range up to $480 \mathrm{mR} / \mathrm{yr}$. The Fall Line, which runs in a general southwest to northeast direction from Evans, Ga., toward Columbia, S. C., is the margin of the ancient coastal line of the Atlantic Ocean. To the east of the Fall Line, base rock is covered with sediments deposited when this area was covered by the ocean in ages past. To the west of the Fall Line, base rock protrudes at the ground surface at many locations, including stream valleys and highway cuts.

\section{CESIUM-137 INVENTORY IN SWAMP SEDIMENTS}

An inventory of ${ }^{137} \mathrm{Cs}$ was made from the 1974 EG\&G aerial survey data using the assumptions that most of the radioactivity was in the upper three inches of soil and decreased exponentially with depth (this is typical for weapons test fallout ${ }^{137} \mathrm{Cs}$ ). The inventory calculated using these assumptions is shown in Table 6. 
TABLE 6

Cesium-137 Inventory Based on EG\&G Aeroradioactivity Survey in 1974

On Plant - Below Road $A^{\alpha}$

Curies

Four Mile Creek from Road A to and including 0.91 swamp

Pen Branch from Road A to and including swamp

Steel Creek from Road A to swamp

2.81

Stee1 Creek delta and swamp

9.96

Lower Three Runs Creek to and including

swatip

Total

$\mathbf{1 5 . 6 5}$

Off PZant

Plant boundary near Steel Creek to Little $\quad 3.00$ Hel1 Landing

Little Hel1 Landing to Lower Three Runs Creek 0.24 swamp

Total

3.24

Total Below Road A

18.89

a. SRP Road A is an extension of South Carolina Highway 125 and crosses the SRP site on a line paralleling the Savannah River Swamp.

The 1974 ground survey, in which soil samples were taken to depths ranging from 7 to 10 inches and analyzed by $2-1 / 2-$ in. increments, showed that $70 \%$ of the radioactivity was in the top $2-1 / 2$ in. of soil but was detectable at depths up to 10 in. (Appendix C). A ${ }^{137} \mathrm{Cs}$ isoactivity map (Figure 16) was prepared on the basis of sediment analysis, and from this, it was calculated that $25 \mathrm{Ci}(0.3 \mathrm{~g})$ of ${ }^{137} \mathrm{Cs}$ was deposited in the Creek Plantation Swamp. Considering the depth distribution of the radiocesium, there is good agreement between the inventory made by aerial survey and the inventory made by sediment analyses. The 25-Ci inventory seems more reasonable when compared with the decrease in transport of $200 \mathrm{Ci}$ of ${ }^{137} \mathrm{Cs}$ between SRP Road A and the Savannah River at the Highway 301 Bridge and when compared with on-site deposition (Table 6). 


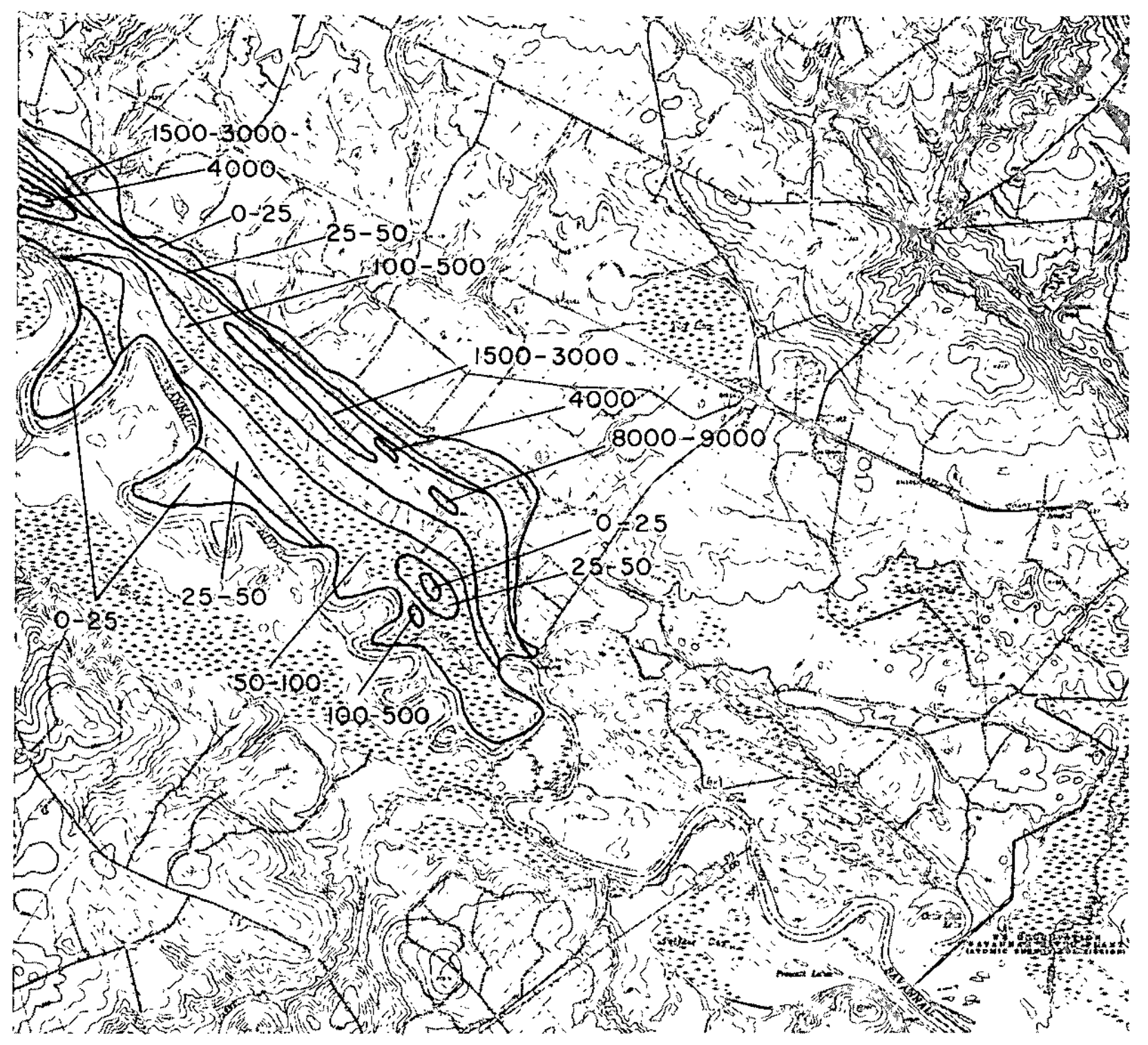

FIGURE 16. Isoactivity Contours from 1974 Ground Survey (Cesium Deposition, $\mathrm{pCi} / \mathrm{cm}^{2}$ ) 


\section{OTHER RADIONUCLIDES IN THE OFF-SITE SWAMP}

During the period that ${ }^{137} \mathrm{Cs}$ was released from the reactor areas, approximately $58 \mathrm{Ci}$ of ${ }^{60} \mathrm{Co}(5.3$ year half-1ife) was also released. ${ }^{60} \mathrm{Co}$ transport in the river was not measurable except during several years of high releases. Data from these periods indicates that up to $60 \%$ of the ${ }^{60} \mathrm{Co}$ released was measurable in transport in the river, and that as much as $23 \mathrm{Ci}$ may have been initially retained in on-site streams and in the on-site and off-site swamp.

Radioanalysis of sediments from the Creek Plantation Swamp showed that ${ }^{60} \mathrm{Co}$ deposition was confined to approximately the centerline of the effluent flow shown in Figure 3 . The highest concentration found was $14 \mathrm{pCi} / \mathrm{g}$ in the top $2 \mathrm{t}$-in. 1 ayer of sediments. The 1974 aerial radiological survey by EG\&G confirmed the location of the ${ }^{60} \mathrm{Co}$. On the basis of the aerial survey, it was calculated that less than $1 \mathrm{Ci}$ of ${ }^{60} \mathrm{Co}$ resides in the Creek Plantation Swamp. The number of soil samples ( 8 out of 157) containing cobalt was insufficient to make an inventory based on radioanalysis. ${ }^{60} \mathrm{Co}$ was not detected in any vegetation or other wildlife samples obtained in the 1974 ground survey.

Approximately $63 \mathrm{Ci}$ of ${ }^{89,90} \mathrm{Sr}$ was released to SRP streams since startup of plant operations. Of this, $52 \mathrm{Ci}$ was measured in transport in the Savannah River at the U. S. Highway 301 bridge, downstream from SRP. Kaolin clay particles have very little sorptive capacity for strontium, and this accounts for the lack of strontium above background in the Creek Plantation sediments. However, ${ }^{0} \mathrm{Sr}$ concentrations ranging from $<1.2$ to $2.5 \mathrm{pCi} / \mathrm{g}$ were detected in composited samples of vegetation from the Creek Plantation Swamp (Appendix C). This is only 3 to 6 times the concentration of $0.4 \mathrm{pCi} / \mathrm{g}$ found in off-site farm produce ${ }^{2}$ (collards) resulting from fallout from nuclear weapons tests.

No other radionuclides of SRP origin were detected in the analysis of Creek Plantation Swamp soil, vegetation, or wildlife samples.

\section{CESIUM-137 IN RIVER SEDIMENTS}

Fine clay particles are kept in suspension by the turbulence. of normal river flow. Exceptions are locations where water velocity is low, such as the inside of river meanderings, entries of dead oxbows, and the downstream side of pilings. At these locations, fine particles of sand and clay settle. Sediments from such locations upstream of SRP normally have about $1 \mathrm{pCi} / \mathrm{g}$ of ${ }^{13}{ }^{7} \mathrm{Cs}$ 
or less from weapons test fallout. Dry-land soil in the Central Savannah River Area also contains about $1 \mathrm{pCi} / \mathrm{g}$ in the surface soil. Sediments from river locations downstream from SRP ranged from about $2 \mathrm{pCi} / \mathrm{g}$ at U. S. Highway 301 to $6.5 \mathrm{pCi} / \mathrm{g}$ at S.C. Highway 119 (C1yo, Ga.). No surface deposit of ${ }^{137} \mathrm{Cs}$ was detected in the 1974 aerial survey below Lower Three Runs Creek down to the river estuary on either side of the river, with the exception of trace levels in two locations in the off-site swamp just downstream from Lower Three Runs Creek.

Suspended particles that are transported to the river estuary flocculate and settle in the Savannah, Ga., harbor. This flocculation is caused by the tidal salt water intrusion in the harbor. Because this is a continuous process, the U. S. Army Corps of Engineers conducts a program of harbor dredging so that the harbor can accommodate sea-going vessels. Before 1957, the dredge sediments were pumped to Hutchinsons Island in the harbor. Since 1957, dredge sediments have been disposed of on Barnwell Island in the harbor. ${ }^{137} \mathrm{Cs}$ in pre-1957 sediments on Hutchinsons Island, about 500 acres in area and $8 \mathrm{ft}$ deep, ranged from $0.1 \mathrm{pCi} / \mathrm{g}$ at the bottom of the spoil to $2.0 \mathrm{pCi} / \mathrm{g}$ at the top. Post-1957 sediments on Barnwel1 Island contained from 1.3 to $2.7 \mathrm{pCi} / \mathrm{g}$ (average: $2.1 \mathrm{pCi} / \mathrm{g}$ ) of ${ }^{137} \mathrm{Cs}$ fairly evenly distributed in a 2000-acre area throughout a depth of about $13 \mathrm{ft}$ of spoil. A summary of the cesium concentration in river and harbor sediments is given in Table 7 .

\section{TABLE 7}

Sediments from River and Harbor

$$
{ }^{137} \mathrm{Cs}, \mathrm{pCi} / \mathrm{g}
$$

River Upstream from SRP

0.4

River Downstream (below Lower Three

1.9 Runs Creek)

River at U.S. Highway 301

4.1

River at S.C. Highway 119 (C1yo)

6.5

Harbor
Dredge spoil before $1957^{\alpha}$
$0.1-2.0$
Dredge spoil after $1957^{b}$
$1.3-2.7$

a. Savannah Harbor dredge sediments on thutchinsons Island, Ga., not used since 1957.

b. Savannah Harbor dredge sediments on Barnwel1 Island, S. C.., in use since 1957. 


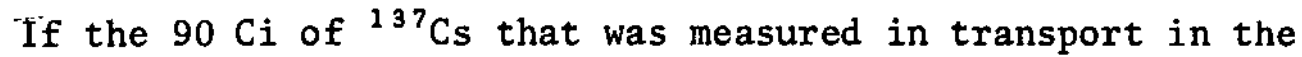
river is assumed to be distributed uniformly in the post-1957 dredge spoil, an area of spoil of about $7 \mathrm{~km}^{2}$ (2.7 square miles) would be required. The area of the post-1957 spoil is approximately 3.1 square miles and contains about $105 \mathrm{Ci}$. An unknown amount of this (perhaps as much as half) could be attributed to fallout cesium since surface soils involved in munoff to the river contain about $1 \mathrm{pCi} / \mathrm{g}$ of ${ }^{137} \mathrm{Cs}$.

Some farming is currently carried out on pre-1957 sediments on Hutchinsons Island (corn, cucumbers, and soybeans). Samples of these farm crops contained less than $0.6 \mathrm{pCi} / \mathrm{g}$ of ${ }^{137} \mathrm{Cs}$ (sensitivity of analysis). Short-lived fission product concentration $\left({ }^{103,106} \mathrm{Ru},{ }^{95} \mathrm{Zr}-{ }^{95} \mathrm{Nb}\right.$, and $\left.{ }^{141,144} \mathrm{Ce}\right)$ from fallout ranged from 1 to $11 \mathrm{pCi} / \mathrm{g}$ in the farm produce.

\section{RADIOACTIVITY IN WILDLIFE}

Furbearing animals were obtained from the vicinity of Upper Three Runs Creek (control) for comparison with animals obtained from land bordering the swamp near Steel Creek. Results of radioanalysis of muscle tissue and liver tissue of these animals are shown in Table 8. There is no apparent correlation of cesium concentration in animals with the cesium in sediment and vegetation in the bordering swamp. This indicates little utilization of the swamp by the animals as a source of food.

TABLE 8

Cesium in Animals (Average VaTues for 1974)

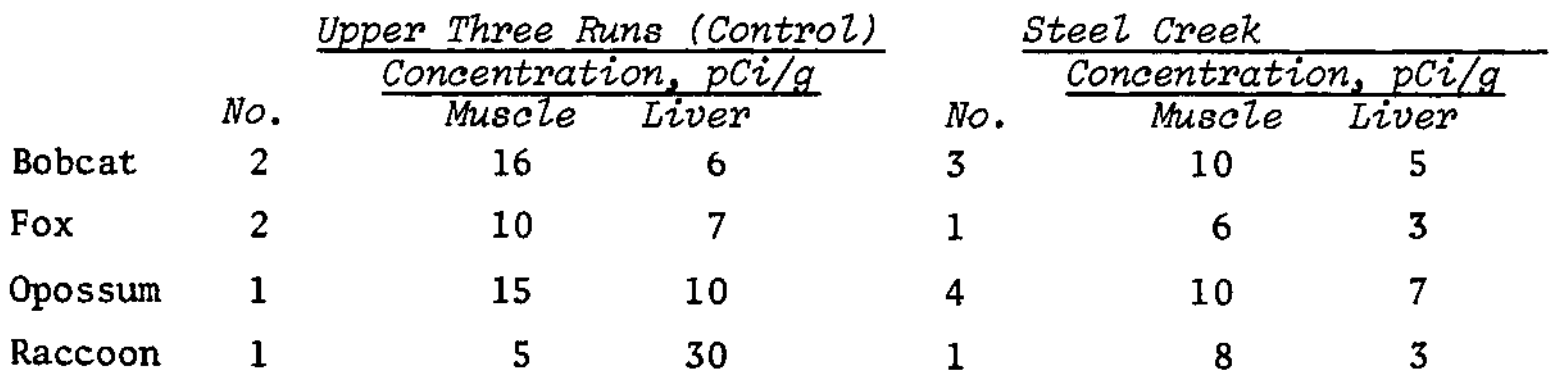

Deer taken during the 1973 public hunts at SRP were monitored for ${ }^{137} \mathrm{Cs}$ with a mobile gamma monitor. Representative samples of deer muscle were taken for laboratory radioanalysis to corroborate the field monitoring. The average concentration of ${ }^{137} \mathrm{Cs}$ in deer from the area bordering the Savannah River Swamp between Steel Creek and the plant perimeter was $8 \mathrm{pCi} / \mathrm{g}$, comparable to the $6 \mathrm{pCi} / \mathrm{g}$ average for all deer taken on the SRP site (Table 9). The deer containing the highest concentration of ${ }^{137} \mathrm{Cs}(31 \mathrm{pCi} / \mathrm{g})$ was taken near Lower Three Runs Creek at Pattersons Mill Bridge. 
TABLE 9

Cesium In Deer From 1973 Deer Hunts

\begin{tabular}{|c|c|c|c|c|}
\hline & & Conc & atrat & on, \\
\hline & Number & $\overline{M a x}$ & $\operatorname{Min}$ & $A v g$ \\
\hline Stee1 Creek $^{a}$ & 11 & 15 & 4 & 8 \\
\hline A11 SRP & 1158 & $31^{b}$ & $<1$ & 6 \\
\hline
\end{tabular}

a. Adjacent to swamp between Steel Creek and plant boundary.

b. Near Pattersons Mill Bridge on Lower Three Runs Creek.

The average concentration of ${ }^{137} \mathrm{Cs}$ in deer taken from all areas of SRP during the 1973 public hunts are comparable to concentrations in the general Central Savannah River Area. Deer from the coastal plain east and south of SRP tend to have ${ }^{137} \mathrm{Cs}$ concentrations several times higher than SRP deer, with concentrations as high as $44 \mathrm{pCi} / \mathrm{g}$ (Fort Stewart, Ga.) measured by SRP laboratories in deer samples from Alabama, Georgia, Virginia, and South Carolina. ${ }^{3}$

Neither Steel Creek nor the Savannah River Swamp provide many habitat locations attractive to migratory ducks. Several areas in Stee 1 Creek near Road A and Road B are wide and shallow, have slow moving water, and are relatively unobstructed by trees. Wood ducks are known to nest in these areas, and the cesium concentration in flesh from these ducks reflects their cesium-contaminated environment (Table 10). Transient ducks from the Steel Creek Swamp have ${ }^{137} \mathrm{Cs}$ concentrations of $8 \mathrm{pCi} / \mathrm{g}$, comparable to transient ducks obtained from Par Pond.

TABLE 10

Cesium In Ducks (1974)

Location

Number $\frac{\text { Concentration, } p C i / g}{\operatorname{Max} \operatorname{Min} A v g}$

Steel Creek, Road B

2

Steel Creek, Road A

Stee1 Creek Swamp

Par Pond

$\begin{array}{rrrr}2 & 30 & 20 & 25 \\ 5 & 105 & 12 & 67 \\ 2 & 8 & 8 & 8 \\ 8 & 12 & 1 & 7\end{array}$


Two small creeks drain across the Creek Plantation into the Creek Plantation Swamp. Drainage from these creeks maintains a slough of standing water that runs throughout most of the length of the swamp. This slough ranges from a few inches in depth to over six feet deep in some locations. Whole fish obtained from three locations in the slough were analyzed for cesium content. of the 28 fish analyzed (Table 11), cesium concentrations ranged from 0.5 to $6 \mathrm{pCi} / \mathrm{g}$ with an average of $3.9 \mathrm{pCi} / \mathrm{g}$. In comparison, over 300 fish obtained from the Savannah River (upstream from, adjacent to, and downstream from SRP) ranged up to $4 \mathrm{pCi} / \mathrm{g}$ with an average of less than $0.3 \mathrm{pCi} / \mathrm{g}$, the sensitivity of analysis.

\section{TABLE 11}

Cesium In Fish (1974)

\begin{tabular}{|c|c|c|c|}
\hline \multirow[t]{2}{*}{ Creek Plantation Swamp } & \multirow[t]{2}{*}{ Number } & \multicolumn{2}{|c|}{$\begin{array}{l}\text { Concentration, } \\
\mathrm{pCi} / \mathrm{g}\end{array}$} \\
\hline & & $\overline{M a x}$ & $A v g$ \\
\hline Bream & 23 & 6.1 & 2.7 \\
\hline Jack & 2 & 3.5 & 3.5 \\
\hline Catfish & 3 & 6.1 & 5.5 \\
\hline & & Ave & +3.9 \\
\hline $\begin{array}{l}\text { Savannah River } \\
\text { Upstream }\end{array}$ & 114 & 1.6 & $<0.3$ \\
\hline Adjacent to SRP & 82 & 2.5 & $<0.3$ \\
\hline Downstream & 137 & 4.0 & $<0.3$ \\
\hline
\end{tabular}

a. Savannah River fish were predominantly bream and catfish.

of the vegetation growing in contaminated sediments in the Creek Plantation Swamp, twigs and 1 imbs from trees had 1 ower ${ }^{13}{ }^{7} \mathrm{Cs}$ concentrations than the more-shallow-rooted grasses and understory bushes. Table 12 compares cesium concentrations in vegetation from two areas of the swamp having the highest cesium concentration in sediments. The maximum concentration of $235 \mathrm{pCi} / \mathrm{g}$ was found in understory leaves from a location one-mile northwest of Little Hel1 Landing (Appendix C). In comparison, ${ }^{137} \mathrm{Cs}$ concentration in agricultural products from the areas surrounding SRP contained a maximum of $0.4 \mathrm{pCi} / \mathrm{g}$ (in collards). Other agricultural products containing from 0.04 to $0.11 \mathrm{pCi} / \mathrm{g}$ of ${ }^{137} \mathrm{Cs}$ were plums, oats, rye, wheat, corn, chicken, and beef. ${ }^{2}$ The cesium in farm produce was of weapons test origin. 
TABLE 12

Cesium In Vegetation (1974)

Plant Perimeter

Concentration, $p C i / g$

Twigs-Limbs Grass-Leaves

1 mile NW of Little Hell Landing

$<0.4-18$ (Ash)

2-122 (Grass)

<0.3-12 (Ash) 1-235 (Understory

leaves)

Off-Plant Agricultural

$0.4 \max$

Products (fallout)

(collards)

A summary of average ${ }^{137} \mathrm{Cs}$ concentrations in wildlife is given in Table 13. From these data, it appears that wildlife make very little utilization of the swamp as a source of food.

TABLE 13

${ }^{137} \mathrm{Cs}$ in Wildlife

$$
\begin{gathered}
A v g{ }^{137} \mathrm{Cs}, \\
\mathrm{pCi} / \mathrm{g}
\end{gathered}
$$

Bobcat $\quad 10$

Fox 6

Opossum $\quad 10$

Raccoon 8

Deer 8

Ducks 7

Fish $\quad 3.9$

\section{DOSE COMMITMENT FROM CONSUMPTION OF WILDLIFE}

Table 14 shows the dose commitment from the consumption of wildlife containing a ${ }^{137} \mathrm{Cs}$ concentration of $10 \mathrm{pCi} / \mathrm{g}$ for different rates of consumption. A consumption rate of $0.51 \mathrm{~b} /$ week has generally been used for purposes of estimating dose commitment to the occasional consumer of river fish. A hypothetical person eating only meat and fish from the swamp could conceivably consume as much as $7 \mathrm{lb} /$ week of wildlife at the $10 \mathrm{pCi} / \mathrm{g}$ concentration and would receive a whole body dose commitment of $104 \mathrm{mrem}$ if this rate of consumption persisted for a period of one year. 
TABLE 14

Dose from Consumption of Wildlife Containing $10 \mathrm{pCi} / \mathrm{g}$ of ${ }^{137} \mathrm{Cs}$

$\begin{array}{lc}\text { Amount Consumed, } & \begin{array}{l}\text { Dose Commitment, } \\ \text { mrem/year of } \\ \text { consumption }\end{array} \\ 0.5^{\text {a }} & 7 \\ 1 & 15 \\ 2 & 30 \\ 3 & 44 \\ 4 & 59 \\ 5 & 74 \\ 6 & 89 \\ 7 & 104\end{array}$

a. Dose $=0.74 \mathrm{C}$ (for $0.5 \mathrm{lb} /$ week),
where $\mathrm{C}=$ concentration in flesh, $\mathrm{pCi} / \mathrm{g}$.

\section{DOSE FROM RESIDENCE IN THE SWAMP}

In many places, the Creek Plantation Swamp is penetrable only with great difficulty because of sloughs and undergrowth. During the summer, it harbors a large number of snakes (including moccasins) and insects, while during the winter (January through April), it is frequently flooded. There are no known permanent residents in the swamp, nor is it likely because of the inhospitable conditions existing there. However, if the pessimistic assumption is made that a person resided at the location of highest gamma dose rates $(460 \mathrm{mR} / \mathrm{yr}$ ) near the SRP boundary for the $77 \%$ of the year when the swamp is not flooded, he could conceivably receive an external gamma exposure of $357 \mathrm{mR}$. Such a person is highly unlikely ever to exist. More likely would be a person (or persons) who occasionally enters the swamp for fishing when the swamp is flooded, in which case, most of the gamma radiation would be shielded by water. Other forms of recreation, including hunting and launching boats in the Savannah River at the Steel Creek Landing, would expose persons for a few hours to a few hundreds of hours per year, resulting in doses ranging from less than one mrem to a few tens of mrem per year if the exposure occurred in the area of highest dose rates. 
HYPOTHETICAL DOSES TO EXPOSED INDIVIDUALS

The previous two sections discussed maximum annual whole body dose to a hypothetical person with very unusual living habits. Table 15 summarizes the dose to this individual.

\section{TABLE 15}

Hypothetical Maximum Dose To Man

mrem/year

Residence in swamp when not flooded, 357 $77 \%$ of year at maximum external gamna dose rate of $53 \mu \mathrm{R} / \mathrm{hr}$

Consumption of one pound/day of wildlife at $10 \mathrm{pCi} / \mathrm{g}$

Tota1 Dose

104

461

Natural annual dose from internal

and external sources in 10,000

square mile area surrounding SRP

$$
\text { Avg }
$$

$\operatorname{Max}$

Table 15 also shows that the annual dose from natural sources, both internal and externa1, averages $120 \mathrm{mrem} /$ year but ranges up to $500 \mathrm{mrem} /$ year for persons living in areas of granite outcroppings at the Fall Line. These doses occur in a 10,000-square-mile area encompassing and including the SRP site. Thus, the hypothetical person could receive a dose up to four times the average dose in this area (not including his natural exposure) and comparable to the maximum natural dose of 500 mrem found in outcrop areas.

His dose of 461 mrem (incremental dose above natural dose) would be within the maximum guidelines of $500 \mathrm{mrem} / \mathrm{year}$ specified for an individual in AEC Manual Chapter 0524 and Code of Federal Regulations, Title 10, Part 20.

\section{ACKNOWLEDGMENTS}

The author gratefully acknowledges the contributions of the SRP Health Physics Environmental Monitoring Group and the firm of EG\&G of Las Vegas, Nevada. 


\section{APPENDIX A}

RADIATION MEASUREMENTS IN THE SAVANNAH RIVER SWAMP FROM STEEL CREEK TO LITTLE HELL LANDING ${ }^{\alpha}$ (FS-11 SURVEY, 1974)

\begin{tabular}{|c|c|c|c|c|c|c|c|c|c|c|}
\hline Distonce & Radiat & on $1 \mathrm{~m}$ & dove Gro & ind at & Various & River & Mizes & STransect & Numbers), & , $\mu R / h r$ \\
\hline From & & & $139.5=$ & & & & & & & \\
\hline $\begin{array}{l}\text { River, } \\
\text { meters }\end{array}$ & $\begin{array}{c}141.5 \\
\text { (1) }\end{array}$ & $\begin{array}{l}140.8 \\
(2)\end{array}$ & $\begin{array}{c}140.8 \\
(3)\end{array}$ & $\begin{array}{l}139 \\
(4)\end{array}$ & $\begin{array}{c}138.5 \\
(5)\end{array}$ & $\begin{array}{l}137 \\
(6)\end{array}$ & $\begin{array}{c}136.3 \\
(7)^{3}\end{array}$ & $\begin{array}{c}135.7 \\
(8)\end{array}$ & $\begin{array}{c}135.3 \\
(9)\end{array}$ & $\begin{array}{r}134.4 \\
(10)\end{array}$ \\
\hline 0 & 17 & 12 & 8 & 8 & 8 & 9 & 9 & 9 & 10 & 18 \\
\hline 30 & 14 & 13 & 9 & 9 & 8 & 10 & 8 & 10 & 10 & 22 \\
\hline 61 & 15 & 12 & 8 & 8 & 8 & 10 & 9 & 11 & 10 & 10 \\
\hline 91 & 18 & 12 & 9 & 8 & 9 & 10 & 9 & 10 & 10 & 8 \\
\hline 122 & 17 & 15 & 10 & 8 & 8 & 10 & 9 & 11 & 10 & \\
\hline 152 & 17 & 13 & 10 & 8 & 10 & 10 & 10 & 11 & 10 & \\
\hline 183 & 17 & 13 & 10 & 9 & 9 & 10 & 9 & 10 & 11 & \\
\hline 213 & 18 & 13 & 10 & 10 & 9 & 10 & 9 & 12 & 12 & \\
\hline 244 & 23 & 13 & 10 & 13 & 8 & 9 & 8 & 10 & 10 & \\
\hline 274 & 18 & 15 & 10 & 13 & 8 & 9 & 9 & 10 & 11 & \\
\hline 305 & 20 & 15 & 10 & 15 & 9 & 9 & 9 & 10 & 10 & \\
\hline 335 & 23 & 14 & 10 & 17 & 10 & $b$ & 9 & 10 & 10 & \\
\hline 366 & 25 & 15 & 10 & 20 & 10 & $b$ & 10 & 10 & 10 & \\
\hline 396 & 24 & 14 & 8 & 24 & 10 & 8 & 10 & 10 & 10 & \\
\hline 427 & 24 & 14 & 10 & 29 & 12 & 7 & 10 & 9 & 8 & \\
\hline 457 & 26 & 15 & 10 & 37 & 10 & 10 & 9 & 8 & 12 & \\
\hline 488 & 32 & 16 & 9 & 22 & 14 & 11 & 9 & 10 & 12 & \\
\hline 518 & 40 & 14 & 10 & 32 & 15 & 12 & 8 & 10 & 12 & \\
\hline 549 & 57 & 14 & 8 & 20 & 20 & 13 & 8 & 11 & 23 & \\
\hline 579 & 57 & 14 & 8 & 20 & 43 & 13 & 9 & 10 & 18 & \\
\hline 610 & 57 & 14 & 9 & 45 & 33 & 16 & 8 & 12 & 25 & \\
\hline 640 & 50 & 17 & & 20 & 77 & 16 & $b$ & 10 & 27 & \\
\hline 671 & 22 & 16 & & 17 & 40 & 15 & $b$ & 10 & 23 & \\
\hline 701 & 12 & 17 & & 9 & $b$ & 30 & $b$ & 11 & 37 & \\
\hline 732 & 9 & 18 & & 8 & $b$ & 20 & $b$ & 12 & 15 & \\
\hline 762 & 8 & 18 & . & & 48 & 37 & $b$ & 13 & 7 & \\
\hline 792 & & 18 & & & 12 & 24 & 50 & 17 & 8 & \\
\hline 823 & & 18 & & & 10 & 26 & 10 & $b$ & & \\
\hline 853 & & 20 & & & & 25 & & $b$ & & \\
\hline 884 & & $b$ & & & & 10 & & 28 & & \\
\hline 914 & & $b$ & & & & & & 9 & & \\
\hline 945 & & 44 & & & & & & & & \\
\hline 975 & & 13 & & & & & & & & \\
\hline
\end{tabular}

\footnotetext{
a. Radiation was measured with NaI detectors, measurements are not corrected for natural
} background; natural background is from 8 to $10 \mu \mathrm{R} / \mathrm{hr}$.

$b$. No measurement because ground was covered with water. 
Page 46 is not included in the original document.

Janie C. Dogies Records administration $5 / 17 / 2000$ 
APPENDIX B

RADIATION MEASUREMENTS (TLD) IN THE SAVANNAH RIVER SW'AMP FROM STEEL. CREEK TO LITTLE HELL LANDING

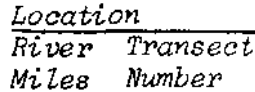

$141.5 \quad 1$

10

4 $140.8 \quad 2$

\section{Distance From River,} meters

0

178

366

640

762
3

139.5

to

140.8

139

4

5

$138.5 \quad 5$

$137 \quad 6$

7

136.37

$135.7 \quad 8$

0

213

427

640

823

945

975

0

335

610

0

305

396

549

610

732

0

533

579

640

823

0

610

762

838

884

0

610

792

823

0

152

274

488

640

790

884

914

$135.5 \quad 9$

$134.4 \quad 10$

Green Pond, near 700 Area (Control)
0

533

640

792

76 $\frac{\text { Radiation, } m R / \text { dogs }}{1974}$

$0.30 \quad 0.27$

$0.35 \quad 0.35$

$0.51 \quad 0.58$

$\begin{array}{ll}1.60 & 1.47\end{array}$

$0.18 \quad 0.17$

$0.22 \quad 0.19$

$0.26 \quad 0.21$

$0.24 \quad 0.19$

$0.28 \quad 0.23$

$0.37 \quad 0.29$

$0.59 \quad a$

$0.19 \quad 0.14$

0.22

0.23

0.23

0.30

0.31

0.49

0.45

0.99

0.22

0.19

0.36

0.61

1.09

0.24

0.22

0.30

0.84

0.85

0.26

0.20

0.19

0.90

0.24

0.22

0.25

0.24

0.24

0.24

0.36

0.64

0.22

0.22

0.46

0.54

0.18

0.20

0.16
0.20

0.21

0.23

0.21

0.25

0.34

$a$
0.22

a. No measurement. 
Page 48 is not included in the original document.

Dannie C. Davies Records Administration $5 / 17 / 2000$ 


\section{APPENDIXC}

RADIOACTIVITY IN VEGETATION AND SOIL IN THE SAVANNAH RIVER SWAMP FROM STEEL CREEK TO LITTLE HELL LANOING (1974)
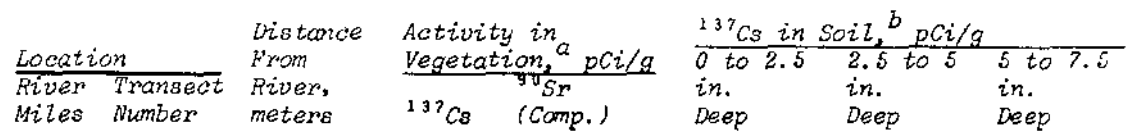

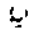

(Comp.)

Deep

Deep

$141,5 \quad 1$

$$
\begin{array}{r}
0 \\
180 \\
370 \\
550 \\
640 \\
760
\end{array}
$$

$140.8-2$

0
210
430
640
880
940
980

$$
\begin{array}{r}
2 \\
20 \\
3 \\
122 \\
22 \\
2
\end{array}
$$

2.0

$\begin{array}{rr}31 & 8 \\ 23 & 7 \\ 126 & 12 \\ 345 & 14 \\ 194 & 75 \\ 3 & 1\end{array}$

$<1$

$\begin{array}{rrrr}139.5 & 3 & 0 & < \\ 10 & & 340 & < \\ 140.8 & & 610 & < \\ 139 & 4 & 0 & \\ & & 310 & \\ & & 400 & 1 \\ & & 530 & 1 \\ & & 610 & 9 \\ & & 730 & \end{array}$

$\begin{array}{rr}138.5 \quad 5 \quad & 530 \\ & 580 \\ & 640 \\ & 820\end{array}$

$137.0 \quad 6$

$$
\begin{array}{r}
0 \\
610 \\
760 \\
840 \\
850
\end{array}
$$

$\begin{array}{rr}136.3 \quad 7 & 0 \\ & 610 \\ & 790 \\ & 820\end{array}$

$135.7 \quad 8$

0
150
270
490
640
790
880
910

$\begin{array}{rr}135.3 \quad 9 & 0 \\ & 530 \\ & 640 \\ & 790\end{array}$

$134.4 \quad 10$

$<1$
1
$<1$
2
144
1

2.0

$<1$
$<1$
$<1$

$<1.2$

2
2
15
19
98
1

1
1
15
36
$<1$

$$
<1.2
$$$$
\begin{array}{r}
<I \\
5 \\
4
\end{array}
$$

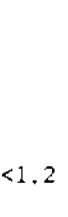

$\begin{array}{rr}1 & 3 \\ 13 & 2 \\ 86 & 17 \\ 72 & 7 \\ 187 & 34 \\ 2 & <1\end{array}$

140

2.5

$$
\begin{array}{r}
1 \\
47 \\
18 \\
235 \\
1
\end{array}
$$

1.3

1.8

$\begin{array}{rr}12 & 4 \\ 4 & <1 \\ 1 & <1 \\ 5 & <1 \\ 6 & 3 \\ 63 & 22 \\ 114 & 6 \\ 5 & 1\end{array}$

$$
<1.2
$$

$$
\begin{array}{r}
2 \\
120 \\
134 \\
1
\end{array}
$$

1.5

$\begin{array}{rrr}1 & 2 & 1 \\ 2 & <1 & <1 \\ 4 & 1 & <1 \\ 9 & 1 & <1 \\ 47 & 6 & <1 \\ 122 & 6 & 1 \\ 3 & <1 & <1\end{array}$$$
\begin{array}{rr}
<1 & 1 \\
1 & <1 \\
43 & 1
\end{array}
$$

2
5
9
26
12
$<1$

$$
\begin{array}{r}
1 \\
<1 \\
<1 \\
<1 \\
<1 \\
1 \\
<1
\end{array}
$$

$\begin{array}{rrr}1 & 1 & 1 \\ 34 & 6 & 1 \\ 140 & 25 & 4 \\ 260 & 44 & 21 \\ 1 & <1 & <1\end{array}$

$\begin{array}{rrr}1 & 2 & 2 \\ 50 & 11 & <1 \\ 160 & 78 & 9 \\ 300 & 17 & 44 \\ 4 & 1 & <1\end{array}$

$\begin{array}{rrr}2 & 2 & 3 \\ 6 & <1 & <1 \\ 527 & 300 & 21 \\ 3 & <1 & <1\end{array}$

$\begin{array}{rr}4 & <1 \\ 13 & 4 \\ 4 & 2 \\ <1 & 3 \\ & <1\end{array}$

1
$<1$

2.3

$\begin{array}{rrr}51 & 5 & 2 \\ 5 & 1 & <1\end{array}$

a. Primarily tree leaves with some grass. Separate analyses of tree limbs and twigs showed concentrations at or near sensitivity of analyses except for three ash trees which showed concentrations from 12 to $18 \mathrm{pCi} / \mathrm{g}$.

b. Concentration in control samples $\sim \mathrm{pCi} / \mathrm{g}$. 
Page 50 is not included in the original document.

Aerie R. Puckett Records Administration $5-17-00$ 


\section{REFERENCES}

I. R. G. Schmidt. Aeroradioactivity Survey and Aereal Geology of the Savannah River Plant Area. South Carolina and Georgia (ARMS-1). USAEC Report CEX-58.4.2, U. S. Geologic Survey and Division of Biology and Medicine, AEC, Washington, D. C. (1962).

2. Environmental Monitoring in the Vicinity of the Savannah River Plant - Annual Report for 1973. USAEC Report DPSPU74-30-1, E. I. du Pont de Nemours \& Co., Savannah River Plant, Aiken, S. C. (1974).

3. W. L. Marter. Radiodotivity in the Environs of Steel Creek. USAEC Report DPST-70-435, E. I. du Pont de Nemours \& Co., Savannah River Laboratory, Aiken, S. C. (1970). 